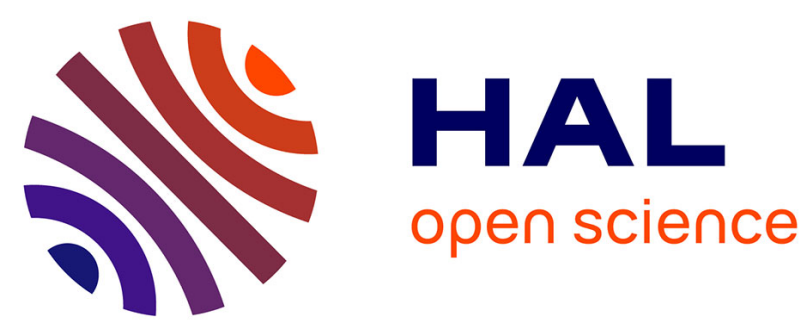

\title{
Spinel Mixed Oxides for Chemical-Loop Reforming: From Solid State to Potential Application
}

Olena Vozniuk, Nathalie Tanchoux, Jean-Marc Millet, Stefania Albonetti, Francesco Di Renzo, Fabrizio Cavani

\section{- To cite this version:}

Olena Vozniuk, Nathalie Tanchoux, Jean-Marc Millet, Stefania Albonetti, Francesco Di Renzo, et al.. Spinel Mixed Oxides for Chemical-Loop Reforming: From Solid State to Potential Application. Stefania Albonetti; Siglinda Perathoner; Elsje Alessandra Quadrelli. Horizons in Sustainable Industrial Chemistry and Catalysis, 178, Elsevier, pp.281-302, 2019, Studies in Surface Science and Catalysis, 10.1016/B978-0-444-64127-4.00014-8 . hal-01967408

\section{HAL Id: hal-01967408 \\ https://hal.science/hal-01967408}

Submitted on 31 Dec 2018

HAL is a multi-disciplinary open access archive for the deposit and dissemination of scientific research documents, whether they are published or not. The documents may come from teaching and research institutions in France or abroad, or from public or private research centers.
L'archive ouverte pluridisciplinaire HAL, est destinée au dépôt et à la diffusion de documents scientifiques de niveau recherche, publiés ou non, émanant des établissements d'enseignement et de recherche français ou étrangers, des laboratoires publics ou privés. 


\section{AUTHOR QUERY FORM}

\begin{tabular}{|c|c|c|}
\hline ELSEVIER & $\begin{array}{l}\text { Book: Studies in Surface Science and } \\
\text { Catalysis } \\
\text { Chapter Number: } 14\end{array}$ & $\begin{array}{l}\text { Please e-mail your responses and any corrections to: } \\
\text { E-mail: omer.m@elsevier.com }\end{array}$ \\
\hline
\end{tabular}

Dear Author,

Please check your proof carefully and mark all corrections at the appropriate place in the proof (e.g., by using onscreen annotation in the PDF file) or compile them in a separate list. Note: if you opt to annotate the file with software other than Adobe Reader then please also highlight the appropriate place in the PDF file. To ensure fast publication of your paper please return your corrections within 48 hours.

For correction or revision of any artwork, please consult http://www.elsevier.com/artworkinstructions.

We were unable to process your file(s) fully electronically and have proceeded by

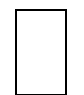

Scanning (parts of) your article

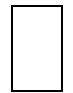

Rekeying (parts of) your article

Scanning the artwork

Any queries or remarks that have arisen during the processing of your manuscript are listed below and highlighted by flags in the proof. Click on the ' $\underline{Q}$ ' link to go to the location in the proof.

\begin{tabular}{|c|c|}
\hline $\begin{array}{l}\text { Location in } \\
\text { Chapter }\end{array}$ & $\begin{array}{l}\text { Query / Remark: } \underline{\text { click on the } Q \text { link to go }} \\
\text { Please insert your reply or correction at the corresponding line in the proof }\end{array}$ \\
\hline$\underline{\text { Q1 }}$ & $\begin{array}{l}\text { As per the specifications, a credit line is always preceded by anyone of the following terms: } \\
\text { "Reproduced with permission from", "From", "Modified from", "Data from", "Based on" or } \\
\text { "Courtesy" instead of the term "Inspired by." Please provide the same in the caption of Fig. 14.4. }\end{array}$ \\
\hline$\underline{\mathbf{Q 2}}$ & $\begin{array}{l}\text { As per the specifications, a credit line is always preceded by anyone of the following terms: } \\
\text { "Reproduced with permission from", "From", "Modified from", "Data from", "Based on" or } \\
\text { "Courtesy" instead of the term "Inspired by." Please provide the same in the caption of Fig. 14.5. }\end{array}$ \\
\hline$\underline{\text { Q3 }}$ & Please check the layout of Table 14.1, and correct if necessary. \\
\hline$\underline{\text { Q4 }}$ & $\begin{array}{l}\text { Please check whether the suggested running head "Spinel Mixed Oxides for Chemical-Loop } \\
\text { Reforming" is appropriate for this chapter. }\end{array}$ \\
\hline$\underline{\text { Q5 }}$ & $\begin{array}{l}\text { Per guidelines, affiliations should appear in English language. Hence, please check and update all } \\
\text { the affiliations. }\end{array}$ \\
\hline
\end{tabular}




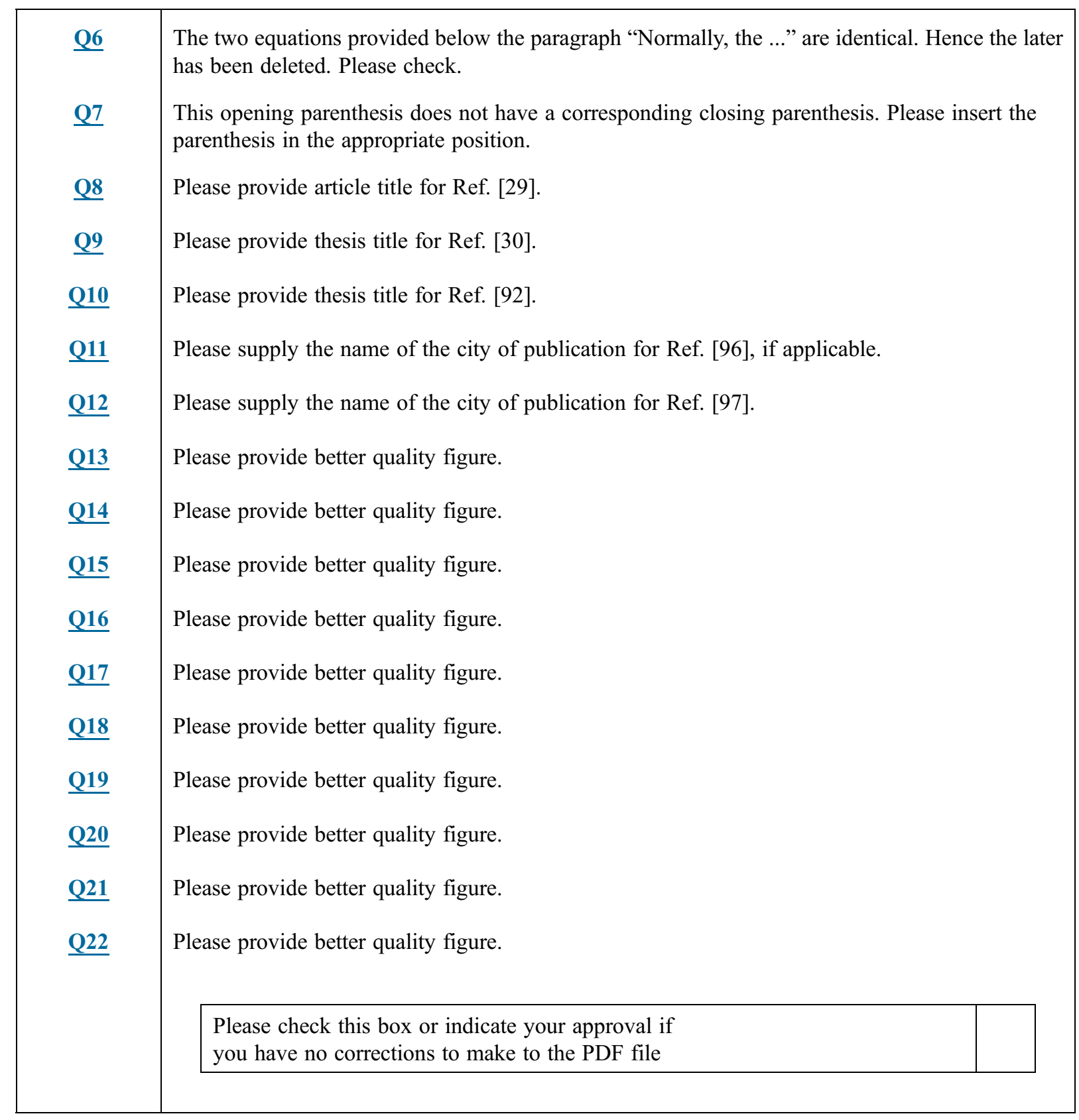

Thank you for your assistance. 


\section{S E C T I O N 3}

\section{ADVANCED SUSTAINABLE \\ CHEMICAL PROCESSES \\ AND CATALYSTS \\ FOR ENVIRONMENT \\ PROTECTION}




\section{H A P T E R}

\section{4}

$\mathrm{C} 0070$

\section{Spinel Mixed Oxides for}

\section{Chemical-Loop Reforming: From Solid State to Potential Application}

Olena Vozniuk ${ }^{*}, \overline{\dagger, 1}$, Nathalie Tanchoux ${ }^{\dagger}$, Jean-Marc Millet ${ }^{*}$, Stefania Albonetti*, Francesco Di Renzo ${ }^{\dagger}$, Fabrizio Cavani*

*Department of Industrial Chemistry “Toso Montanari”, Alma Mater Studiorum Università di Bologna, Bologna, Italy ${ }^{\dagger}$ Institut Charles Gerhardt, UMR 5253 UM-CNRS-ENSCM, Montpellier, France "IRCELyon, UMR 5256 CNRS-Université de Lyon, Villeurbanne, France

\section{O U T L I N E}

1 Introduction

2 Hydrogen Applications 2.1 Fuel Cells

3 Hydrogen Production

3.1 Common Feedstocks

3.2 Common Processes for $\mathrm{H}_{2}$ Production

3.3 Hydrogen Via Reforming Processes

4 Hydrogen Via Alternative Processes

4.1 Water Splitting

4.2 Hydrogen Via Chemical-Looping (CL) Processes

5 Chemical-Loop Reforming (CLR) for Hydrogen Generation
5.1 Oxygen Carrier Materials

5.2 Spinel Oxides as Oxygen Carrier Materials

5.3 Spinel Oxides for Methanol Chemical-Loop Reforming

5.4 Spinel Oxides for Ethanol Chemical-Loop Reforming

5.5 Summary on Spinel Oxides as Oxygen Carrier Materials

6 Conclusions
References

Further Reading

np0010 ${ }^{1}$ Present address: Department of Heterogeneous Catalysis, Max Planck Institute for Coal Research, Mülheim, Germany. 
4

s0010

p0010 Current processes for the industrial production of hydrogen are mainly based on the reforming of natural gas/naphtha or coal gasification. Such processes are highly energy demanding. Hence, less energy-intensive and more sustainable technologies, exploiting renewable feedstocks (such as biomass, bio-alcohols, and water) and renewable primary energy sources (e.g., sunlight, wind, wave, or hydropower), appear to be very attractive for both industrial and consumer applications. A variety of new technologies offering a nonfossil based route for hydrogen production are in a different stage of development, and each offers unique opportunities, benefits, and challenges [1-10].

p0015 Chemical-looping approach for hydrogen production is one of the possible ways to produce high-purity $\mathrm{H}_{2}$ starting from either conventional or renewable sources. The main principle of any looping technology is ingrained in the second law of thermodynamics and applied to enhance exergy efficiency of the process [11]. Initially, the chemical-looping process for hydrogen generation was introduced as a "steam-iron" process in 1913 by Lane et al. [11,12]. At present, any process that aims to produce hydrogen via looping technology is referred to a "chemical-looping hydrogen" (CLH), or "chemical-looping water splitting" (CLWS) process, which usually consists of two spatially or temporarily separated steps: reduction and oxidation. Thus, different from a classical steam methane reforming (SMR), separation costs can be avoided by splitting the process into two alternated steps in order to separate $\mathrm{H}_{2}$ and $\mathrm{CO}_{x}$ streams. Generally, the reduction step is used to transfer oxygen from an oxygen carrier material to a reducing fuel. The reduced oxygen carrier is then regenerated with steam, which enables the production of high-purity hydrogen without an additional separation step. The chemical-looping process can be performed using a number of different reductants, such as gas from coal [13] or biomass [14-16] gasification, light hydrocarbons reforming [17], methane [18-20], a $\mathrm{CH}_{4} / \mathrm{CO}_{2}$ and $\mathrm{CH}_{4} / \mathrm{H}_{2}$ mixture [20,21], pyrolysis oil [22,23], methanol [24], and pure $\mathrm{H}_{2}$ (as a method for $\mathrm{H}_{2}$ storage) $[25,26]$. Furthermore, the nature of the oxide, used as the ionic oxygen and electron carrier, and the reaction conditions are important parameters because they determine the potential for low costs and high efficiency of this process in order to have a commercial impact.

\section{HYDROGEN APPLICATIONS}

Hydrogen is one of the key starting materials p0020 used in the chemical industry with an annual worldwide production of about 50 million tons, Currently, the largest amount ( $95 \%$ ) of the total manufactured hydrogen is consumed mainly by two industrial segments: the chemical sector, accounting for $65 \%$ of the market share (ammonia and methanol synthesis $\sim 63 \%$; liquid hydrocarbons and higher alcohols synthesis $\sim 2 \%$ ), and the refining sector, which accounts for $30 \%$ of the market share (hydrotreating and hydrocracking processes for obtaining high-grade petrochemical products). The other present uses, with $\sim 5 \%$ of the total consumption, include the food industry (sorbitol and fat processing), the metallurgical industry (direct reduction of iron ore), the semiconductor industry, etc. (Fig. 14.1).

In the near future, the possibility to produce p0025 hydrogen in a sustainable manner on the larger scale will boost research landmarks to search for new technological platforms for direct transformation of captured $\mathrm{CO}_{2}$ to its hydrogenated C1-counterparts: formic acid $(\mathrm{HCOOH})$, formaldehyde $\left(\mathrm{H}_{2} \mathrm{CO}\right)$, methanol $\left(\mathrm{CH}_{3} \mathrm{OH}\right)$, and methane $\left(\mathrm{CH}_{4}\right)$ [27]. Highly reduced methanol is indeed the key molecule for the methanol economy and remains obviously a target molecule of choice in terms of its further use in MTHprocesses, as well as $\mathrm{H}_{2}$-storage and carriers in 
B978-0-444-64127-4.00014-8, 00014

2 HYDROGEN APPLICATIONS

\begin{tabular}{|c|l|l|}
\hline INDUSTRIAL SECTOR & \multicolumn{1}{|c|}{ KEY APPLICATIONS } & $\mathrm{H}_{2}$ demand \\
\hline CHEMICAL $65 \%$ & $\begin{array}{l}\text {-AMMONLA PRODUCTION } \\
\text { (mix. } \mathrm{H}_{2}+\mathrm{N}_{2} \text { ) } \\
\text {-METHANOL PRODUCTION } \\
\left.\text { (mix. } \mathrm{H}_{2}+\mathrm{CO}\right)\end{array}$ & \\
\hline
\end{tabular}

Q13 f0010 FIG. 14.1 Main segments of hydrogen consumption.

fuel cells. It is already produced, albeit mainly from natural gas and coal, at a yearly $>50 \mathrm{Mt}$-scale, with a forecasted annual growth of $4 \%$ [28]. Methane, the totally reduced product from $\mathrm{CO}_{2}$, is still considered as a potent molecule in a power-to-gas concept [29], in which superfluously produced energy by nuclear sources or irregularly produced wind, water, and wolar (WWS) electricity may be converted and stored in the chemical bonds of the methane molecule. The advantage of this concept is that methane can be fed in the already available natural gas infrastructure $[27,30]$.

p0030 In conclusion, there is a fast-growing need for increased hydrogen production, because $\mathrm{H}_{2}$ itself may become an important "energy vector" with key applications as a carbon-free fuel and as a fuel for hydrogen-driven fuel cells for automotive uses. However, there are still several major problems to be overcome before it can be used in this way, including its manufacture, storage, and distribution.

\subsection{Fuel Cells}

s0020

Fuel cells are devices that generate electricity p0035 based on a chemical reaction and are often referred to as continuously operating batteries. They exploit electrolysis reactions in a similar manner to traditional batteries, however, the reagents are constantly supplied to the cell. This is determining the difference compared to the traditional dis-chargeable batteries. There are several kinds of fuel cells, though the main operating principle remains the same: hydrogen atoms (or other fuels) at the anode break down to form electrons and $\mathrm{H}^{+}$ions; the latter ones migrate through the electrolyte/membrane to the cathode, where two $\mathrm{H}^{+}$ions combine with oxygen to form water (also emitting heat), while the electrons run through the electrical circuit, producing a current (Fig. 14.2).

Nevertheless, its applications can vary p0040 depending on the type of hydrogen fed to the

\section{ADVANCED SUSTAINABLE CHEMICAL PROCESSES AND CATALYSTS FOR ENVIRONMENT PROTECTION}




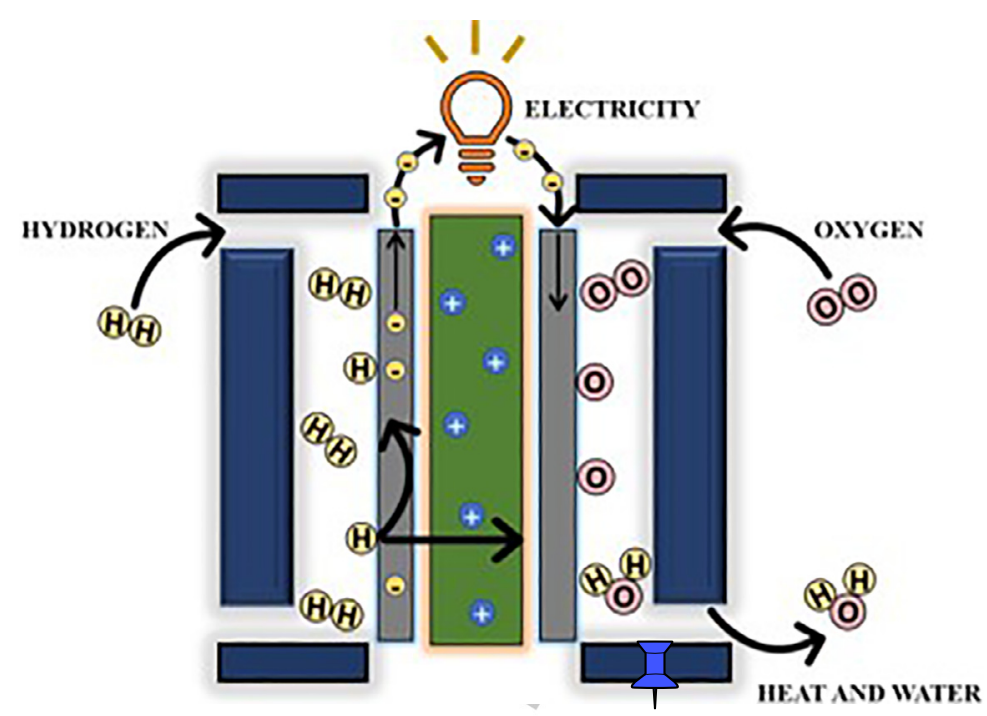

Q14 f0015 FIG. 14.2 General scheme of the fuel cell technology.

anode (they can be chemical elements containing hydrogen) and the nature of the electrolytes (Fig. 14.3).

\section{HYDROGEN PRODUCTION}

\section{s0030 3.1 Common Feedstocks}

p0045 Hydrogen can be produced from different resources, including conventional and wellknown fossil fuels, such as natural gas, naphtha and coal, or from renewable feedstocks or energy sources like biomass, wind, solar, and geothermal energy, etc. Currently, many new technologies, which offer sustainable and nonfossil-based itineraries for hydrogen production, are at a different stage of development, and each one brings its own benefits, opportunities, and challenges. A list of the various feedstocks and process technologies is presented in Fig. 14.4.

\section{s0035 3.2 Common Processes for $\mathrm{H}_{2}$ Production}

p0050 Hydrogen can be produced using many different processes (as illustrated in Fig. 14.5). Thermochemical processes use heat and chemical reactions to release hydrogen from organic materials such as fossil fuels and biomass. Water $\left(\mathrm{H}_{2} \mathrm{O}\right)$ can be split into hydrogen $\left(\mathrm{H}_{2}\right)$ and oxygen $\left(\mathrm{O}_{2}\right)$ using electrolysis or solar energy. Microorganisms such as bacteria and algae can produce hydrogen through biological processes. This section encompasses the most relevant information about the existing processes to manufacture hydrogen.

\subsection{Hydrogen Via Reforming Processes}

Reforming processes are based on the endo- p0055 thermic or exothermic conversion of the feedstock materials with $\mathrm{H}_{2} \mathrm{O} / \mathrm{CO}_{2} / \mathrm{O}_{2}$ converting into a synthetic gas mixture $\left(\mathrm{CO}+\mathrm{H}_{2}\right)$. The most commonly used feedstocks for the reforming processes are methane or other light hydrocarbons obtained from oil. Several chemical processes have been developed to produce hydrogen via the reforming route:

(1) Steam reforming (SMR)

(2) Auto thermal reforming (ATR)

(3) Partial oxidation (POX)

(4) Dry reforming of methane (DMR)

\section{ADVANCED SUSTAINABLE CHEMICAL PROCESSES AND CATALYSTS FOR ENVIRONMENT PROTECTION}




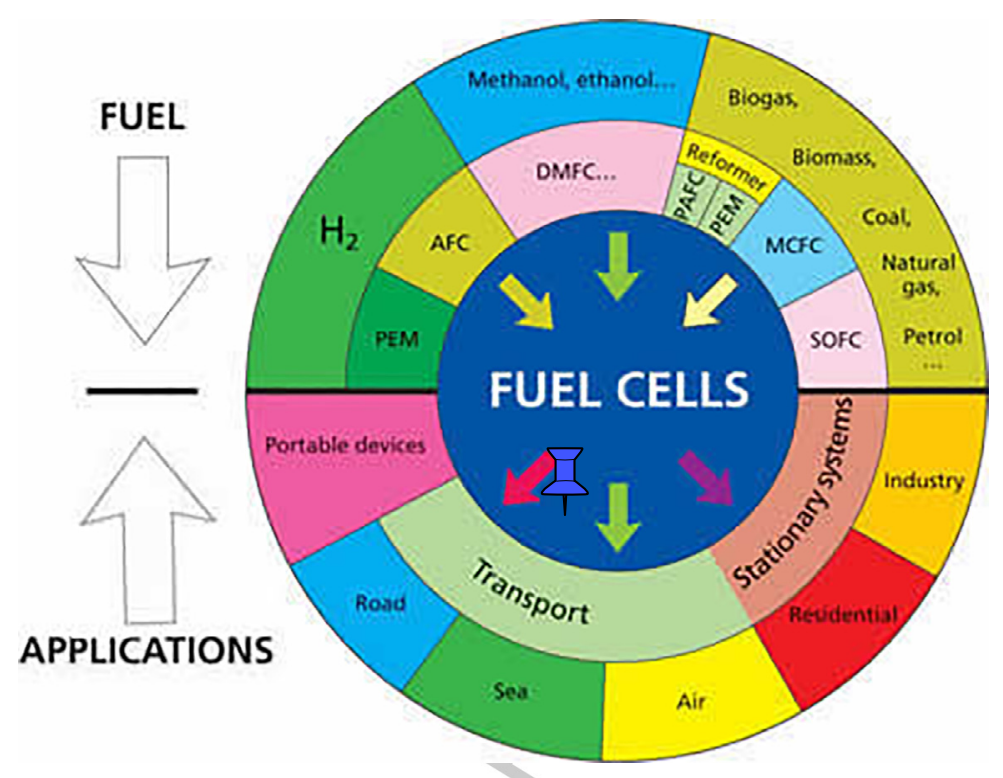

Q15 f0020 FIG. 14.3 Lower segment: main application of the fuel cell technology; Upper segment: fuel and fuel cell types. AFC, alkaline (especially in the space sector); DMFC, direct membrane; $M C F C$, molten carbonate; $P A F C$, phosphoric acid; $P E M F C$, polymer exchange membrane; SOFC, solid oxide. From https:/lec.europa.eu.
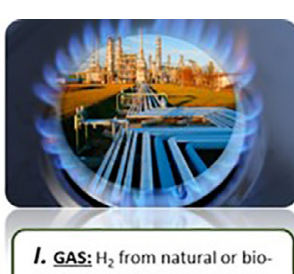
gases via reforming processes

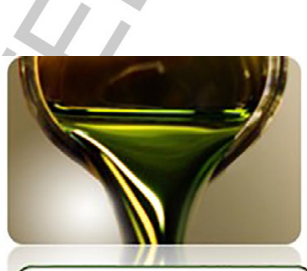

$$
\begin{aligned}
& \text { II. OlL: } \mathrm{H}_{2} \text { from fossil/renewable } \\
& \text { oils via reforming or partial } \\
& \text { oxidation processes }
\end{aligned}
$$

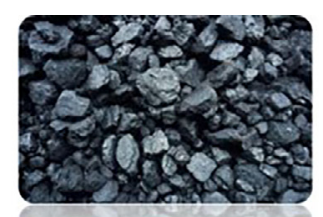

III. COAL: $\mathrm{H}_{2}$ from coal via gasification technology
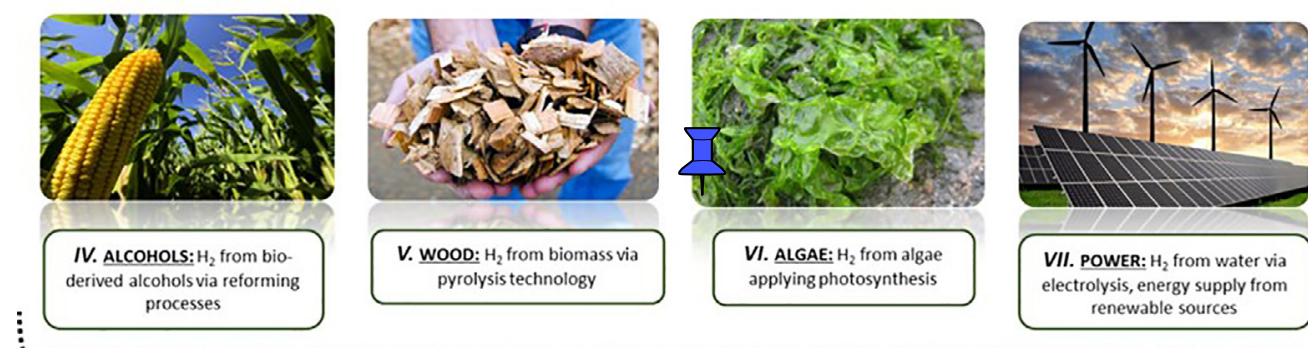

VII. POWER: $\mathrm{H}_{2}$ from water via electrolysis, energy supply from renewable sources

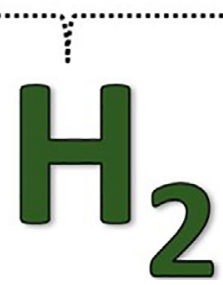

Q1 f0025 FIG. 14.4 Summary of the various feedstocks and process alternatives for $\mathrm{H}_{2}$ production. Inspired by T. Riis, E.F. Hagen, J.S. Q16 Vie, P.J.S. Vie, Ø. Ulleberg, G. Sandrock, Hydrogen Production and Storage; RED Priorities and Gaps, OECD/IEA, 2006. 
8

14. SPINEL MIXED OXIDES FOR CHEMICAL-LOOP REFORMING

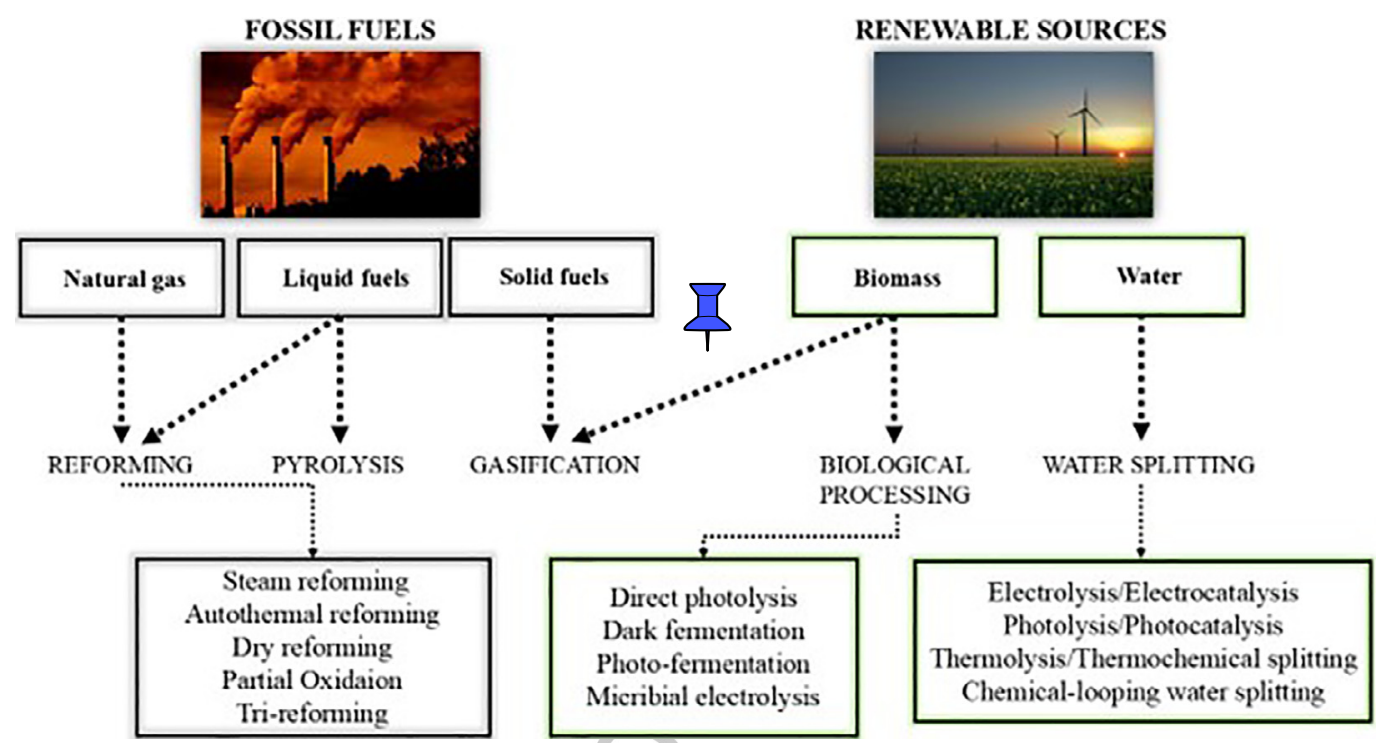

f0030 FIG. 14.5 An overview of existing hydrogen production processes from different sources. Inspired by $D$. Yamaguchi, L. Tang, N. Burke, K. Chiang, L. Rye, T. Hadley, S. Lim, Small Scale Hydrogen Production From Metal-Metal Oxide Redox Cycles, INTECH, 2012.

00030 (5) Combined reforming of methane (CMR)

00035 (6) Reforming with membrane

o0040 (7) Tri-reforming of methane (TMR) [31]

p0095 The first three are widely used industrial processes, whereas the last four are more recent innovative processes developed with the aim to minimize environmental impact and energy consumption together with the improvements of already existing methods.

\section{s0045 3.3.1 Steam Methane Reforming (SMR) and Water Gas Shift (WGS) Reaction}

$$
\mathrm{CH}_{4}+\mathrm{H}_{2} \mathrm{O} \rightarrow 3 \mathrm{H}_{2}+\mathrm{CO} \Delta H^{\circ}=+225.4 \mathrm{~kJ} / \mathrm{mol}
$$

p0105 Steam methane reforming (SMR) is the most common way to produce a hydrogen-rich syngas mixture $\left(\mathrm{H}_{2}+\mathrm{CO}\right)$. A conventional steam reformer unit consists of several hundred fixed-bed reactor tubes filled with a catalyst, which can vary in size and geometry. High temperatures $\left(>600^{\circ} \mathrm{C}\right)$ and low pressures favor the formation of $\mathrm{H}_{2}$ and $\mathrm{CO}$ products (Le Chatelier's principle). However, in practice, the natural gas steam reformer is operated under the pressure of about 20-30 atm (for kinetic reasons), with an exit temperature of $800-870^{\circ} \mathrm{C}$ (but the tube wall temperature can range from $700^{\circ} \mathrm{C}$ up to a maximum hot spot of $920^{\circ} \mathrm{C}$ ), where methane and steam are converted into synthesis gas (mixture of $\mathrm{CO}$ and $\mathrm{H}_{2}$ ). Steam methane reforming is a catalytic process and catalyst properties are dictated by the severe operating conditions, that is, temperatures of $450-950^{\circ} \mathrm{C}$ and steam partial pressures up to 30 bar. Conventional steam reforming catalysts are Ni-based catalysts with $10-20 \mathrm{wt} . \% \mathrm{Ni}$ supported on $\alpha-\mathrm{Al}_{2} \mathrm{O}_{3}$, calcium or magnesium aluminate with a typical lifetime of 3-5years. Cobalt and noble metals $(\mathrm{Ru}, \mathrm{Rh}, \mathrm{Pt}$, and $\mathrm{Pd})$ are also known to be active, however they have not found many applications as SMR catalysts due to their elevated costs. On the other hand, attempts to use cheaper and abundant nonmetallic catalysts have not had commercial success because of the low activity.

\section{ADVANCED SUSTAINABLE CHEMICAL PROCESSES AND CATALYSTS FOR ENVIRONMENT PROTECTION}


p0110 Normally, the subsequent stage of the SMR process includes WGS reactions which further convert carbon monoxide to carbon dioxide, while generating more hydrogen.

$$
\mathrm{CO}+\mathrm{H}_{2} \mathrm{O} \rightarrow \mathrm{H}_{2}+\mathrm{CO}_{2} \quad \Delta H^{\circ}=-42 \mathrm{~kJ} / \mathrm{mol}
$$

p0115 In the first stage, where a high temperature shift reaction is taking place, the gas is mixed with steam and passed over an $\mathrm{Fe} / \mathrm{Cr}$ or $\mathrm{Fe} / \mathrm{Cr} / \mathrm{Mg}$ mixed oxide catalyst at $T=300-450^{\circ} \mathrm{C}$ in a fixed bed reactor, which decreases the carbon monoxide concentration down to $2 \%-3 \%$. In the second stage, the low temperature shift reaction, the mixture of gases is passed over a $\mathrm{Cu} / \mathrm{Zn}$ oxide catalyst at $T=190-220^{\circ} \mathrm{C}$, where the carbon monoxide concentration is reduced to $0.1 \%-0.2 \%$. Further hydrogen purification can be achieved using:

u0010 - Methanation

u0015 - Pressure swing adsorption (PSA)

u0020 - Membrane reactors

\section{s0050 3.3.2 Steam Naphtha Reforming}

p0135 If naphtha is used as the feedstock, an extra reforming stage is needed. The naphtha is first heated to form a vapor, which is then mixed with steam and passed through tubes, heated at $T=450-500^{\circ} \mathrm{C}$ and packed with a catalyst, nickel supported on a mixture of aluminum and magnesium oxides. The main product is methane together with carbon oxides $\left(\mathrm{CO}_{x}\right)$, which is then processed by SMR, as if it were natural gas, followed by the shift reaction.

s0055 3.3.3 Dry Methane Reforming (DMR)

$$
\mathrm{CH}_{4}+\mathrm{CO}_{2} \rightarrow 2 \mathrm{H}_{2}+2 \mathrm{CO} \Delta H^{\circ}=+260.5 \mathrm{~kJ} / \mathrm{mol}
$$

p0145 The DMR process is characterized by a very low intrinsic activity, in addition to the simultaneous occurrence of the reverse water gas shift (RWGS) reaction resulting in a syngas ratio less than a unity. Dry reforming of methane has been investigated with noble ( $\mathrm{Rh}, \mathrm{Ru}, \mathrm{Pd}$, and $\mathrm{Pt}$ ) and nonnoble metal- ( $\mathrm{Ni}, \mathrm{Co}$, and $\mathrm{Fe}$ ) -based catalysts. Noble metal catalysts (Pt/support) [32] have drawn attention for their superior coking resistance, higher stability, and activity, especially for higher temperature applications. However, for large scale industrial applications, development of the active catalyst is still under investigation.

\subsubsection{Autothermal Reforming (ATR)}

Autothermal reforming (ATR) is an important p0150 industrial process used to produce syngas with a low $\mathrm{H}_{2} / \mathrm{CO}$ ratio (from 1.5 to 3 ) desired for synthesis of methanol and higher molecular-weight hydrocarbons (via The Fischer-Tropsch process). The main concept is the combination of noncatalytic partial oxidation and adiabatic catalytic steam reforming, where the reactor temperature is maintained using the heat emitted from the partial oxidation of the hydrocarbon feedstock, typically methane, with a sub-stoichiometric amount of oxygen.

$$
\begin{aligned}
& \mathrm{CH}_{4}+\mathrm{H}_{2} \mathrm{O} \rightarrow 3 \mathrm{H}_{2}+\mathrm{CO} \Delta H^{\circ}=+225.4 \mathrm{~kJ} / \mathrm{mol} \\
& \mathrm{CH}_{4}+\frac{3}{2} \mathrm{O}_{2} \rightarrow \mathrm{CO}+2 \mathrm{H}_{2} \mathrm{O} \quad \Delta H^{\circ}=-520.0 \mathrm{~kJ} / \mathrm{mol}
\end{aligned}
$$

This process was developed by Haldor Topsøe p0155 A/S, with the aim to perform the POX (partial oxidation) and the SR (steam reforming) in a single ATR reactor. The very high temperatures in the ATR unit require a high thermal stability of the catalyst, which is typically a nickel-based catalyst on a stabilized $\mathrm{Al}$ or $\mathrm{Mg}-\mathrm{Al}$ support.

\subsubsection{Partial Oxidation (POX)}

$$
\mathrm{CH}_{4}+\frac{1}{2} \mathrm{O}_{2} \rightarrow \mathrm{CO}+2 \mathrm{H}_{2} \quad \Delta H^{\circ}=36.0 \mathrm{~kJ} / \mathrm{mol}
$$

An alternative way to produce hydrogen is p0165 based on the partial oxidation of a substoichiometric fuel-air mixture which results in a formation of $\mathrm{H}_{2}$-rich syngas. Partial oxidation is an exothermic reaction and, thus, is considered to be more economically feasible than the processes of steam or dry reforming. The exothermic nature of the reaction has certain

\section{ADVANCED SUSTAINABLE CHEMICAL PROCESSES AND CATALYSTS FOR ENVIRONMENT PROTECTION}


10

14. SPINEL MIXED OXIDES FOR CHEMICAL-LOOP REFORMING drawbacks because it induces hot spots on catalysts, arising from a poor heat removal rate, which causes difficulties in operation control. A difference is made between thermal partial oxidation (TPOX) and catalytic partial oxidation (CPOX).

\section{s0070 3.3.6 Thermal (Noncatalytic) Partial Oxidation}

p0170 TPOX is a noncatalytic process in which the feed is partially combusted with a substoichiometric amount of air, oxygen, or enriched air to obtain a $\mathrm{CO}+\mathrm{H}_{2}$ mixture, where the production of syngas depends on the oxygen-to-fuel ratio at an operating temperature range of $1200-1500^{\circ} \mathrm{C}$. Feedstocks used for the TPOX can be almost any carbonaceous material, from natural gas through liquid feeds such as fuel oils, gas oils, and coal. A noncatalytic partial oxidation process was developed by Texaco and Shell which results in high syngas yields at high temperature and pressures [33].

\section{s0075 3.3.7 Catalytic Partial Oxidation}

p0175 CPOX is a catalytic process in which the feed with sub-stoichiometric amount of oxygen (or air) is catalytically converted into a $\mathrm{CO}+\mathrm{H}_{2}$ mixture. The use of a catalyst lowers the required reaction temperature down to $800-900^{\circ} \mathrm{C}$. Commonly used catalysts are noble (Pt, $\mathrm{Rh}, \mathrm{Ir}, \mathrm{Pd})$ or nonnoble (Ni, Co) metal-based catalysts. Catalytic partial oxidation can be performed only if the sulfur content of the feed is below $50 \mathrm{ppm}$, because higher sulfur contents would poison the catalyst (in such cases, noncatalytic partial oxidation is more suitable for the use).

\section{HYDROGEN VIA ALTERNATIVE PROCESSES}

\section{s0085 4.1 Water Splitting}

p0180 Water splitting is a process that enables the production of hydrogen by direct water decomposition in its elements. The energy required to cleave $\mathrm{H}-\mathrm{O}-\mathrm{H}$ bonds can be supplied by different power sources: electrical (current), thermal (heat), or light (electromagnetic radiation). Generally, the difference in water splitting processes is made whenever one or another type of energy source is applied to conduct the reaction, referred to as electrolysis, thermolysis, or photolysis. Electrolytic water splitting is driven by passing the electrical current through the water, where conversion of the electrical energy to chemical energy takes place at the electrodesolution interface through charge transfer reactions in a unit called an electrolyser [34]. Water reacts at the anode to form oxygen and protons, whereas a hydrogen evolution reaction takes place at the cathode. Only 3.9\% of the world's hydrogen demand is satisfied by electrolysis. Although, compared with the conventional SMR, the electrolytic water splitting is described as a less environmentally harmful process with a "zero" $\mathrm{CO}_{2}$ emission (because $\mathrm{O}_{2}$ is the only by-product), electrolysers generally powered by the electricity, which is predominately produced by the combustion of coal or natural gas, resulting in the release of $\mathrm{CO}_{2}$ as a byproduct. Therefore, today's research is increasingly oriented on utilizing renewable harvesting technologies (wind turbines or photovoltaics) to drive the electrochemical/catalytic water-splitting reaction. Photochemical [35,36]/photocatalytic $[37,38]$ water splitting is a promising option for hydrogen production, which is oriented on the reduction of $\mathrm{CO}_{2}$-emission and applications of renewable resources such as water and sunlight. The most important criteria for solar-driven water splitting reactions is the electronic bandgap alignment of the photosensitive material with the redox potential of water [37]. In general, the presence of transition metal cations with a $\mathrm{d}^{0}$ electronic configuration $\left(\mathrm{Ta}^{5+}, \mathrm{Ti}^{4+}, \mathrm{Zr}^{4+}\right.$, $\mathrm{Nb}^{5+}, \mathrm{Ta}^{5+}, \mathrm{W}^{6+}$, and $\mathrm{Mo}^{6+}$ ), or metal cations with a $\mathrm{d}^{10}$ electronic configuration $\left(\mathrm{In}^{3+}, \mathrm{Sn}^{4+}\right.$, $\mathrm{Ga}^{3+}$, and $\left.\mathrm{Ge}^{4+}\right)$ is considered to be important for the efficient photocatalytic materials, the empty $\mathrm{d}$ or sp orbitals of which form the bottom of the respective conduction bands [36]. Over the last decades, significant progress in this field

\section{ADVANCED SUSTAINABLE CHEMICAL PROCESSES AND CATALYSTS FOR ENVIRONMENT PROTECTION}


has been made by an increasing number of research groups where the topic was thoroughly reviewed [39-41].

p0185 Thermal or thermochemical water splitting is another alternative technology to produce hydrogen from water with potentially low or no greenhouse gas emissions [42,43]. This technology has been extensively studied by many research groups, and more than 300 water-splitting cycles with different operating parameters, engineering challenges, and hydrogen production opportunities are described in the literature. Thermochemical water splitting processes require high temperatures $\left(500-2000^{\circ} \mathrm{C}\right)$ to drive a series of chemical reactions, which lead to hydrogen evolution. The chemicals used in the process are reused within each cycle, creating a closed loop that consumes only water and produces hydrogen and oxygen. This technology is an appealing pathway to produce hydrogen-utilizing waste heat from existing nuclear power stations or concentrated (using a field of mirror "heliostats") solar power. However, a realization of renewable-energy solutions for the water splitting reactions on a larger scale remains a challenge, which is dictated by the overall economy of the process and heavily depends on further developments of cost-effectiveness and environmentally benign technologies. Thermochemical water splitting has stimulated the development and growth of a series of new looping technologies that will be described in the next section.

\section{s0090 4.2 Hydrogen Via Chemical-Looping (CL) Processes}

p0190 Chemical-looping processes are alternative processes aimed at generating heat and power (chemical-looping combustion, CLC) or to produce a $\mathrm{CO}+\mathrm{H}_{2}$ mixture (chemical-looping reforming, CLR) or high-purity $\mathrm{H}_{2}$ (chemicallooping hydrogen/chemical-looping water splitting, CLH/CLWS) via looping technology that usually consists of two temporarily or spatially separated steps: reduction and oxidation. During the reduction step, a transfer of oxygen to fuel is mediated by a metal oxide as an oxygen carrier (OC) material $\left(\mathrm{Me}_{x} \mathrm{O}_{y}\right)$, which is put in contact with a reducing stream. The OC is thus reduced and at the same time converts fuel into products, mainly $\mathrm{CO}_{x}, \mathrm{H}_{2} \mathrm{O}$, and $\mathrm{H}_{2}$ (products distribution strongly depends on nature of the reducing agent as well as the nature of the oxygen carrier). Subsequent oxidation steps are performed over the previously reduced material utilizing air/ pure oxygen (I):

$$
\begin{gathered}
\left(\mathrm{I}^{\mathrm{T}}\right) x \mathrm{M}+y(\mathrm{O}) \rightarrow \mathrm{M}_{x} \mathrm{O}_{y} \\
\left(\mathrm{I}^{\mathrm{P}}\right) \mathrm{M}_{x} \mathrm{O}_{y-1}+(\mathrm{O}) \rightarrow \mathrm{M}_{x} \mathrm{O}_{y}
\end{gathered}
$$

or water steam, referred to water splitting technology (II):

$$
\begin{gathered}
\left(\mathrm{II}^{\mathrm{T}}\right) x \mathrm{M}+y \mathrm{H}_{2} \mathrm{O} \rightarrow \mathrm{M}_{x} \mathrm{O}_{y}+y \mathrm{H}_{2} \\
\left(\mathrm{II}^{\mathrm{P}}\right) \mathrm{M}_{x} \mathrm{O}_{y-1}+\mathrm{H}_{2} \mathrm{O} \rightarrow \mathrm{M}_{x} \mathrm{O}_{y}+\mathrm{H}_{2}
\end{gathered}
$$

$\left(\mathrm{I}^{\mathrm{T}}, \mathrm{II}^{\mathrm{T}}\right)$, where ${ }^{(\mathrm{T})}$ index refers to a total reduction of $\mathrm{OC}$,

$\left(\mathrm{I}^{\mathrm{P}}, \mathrm{II}^{\mathrm{P}}\right)$, where ${ }^{(\mathrm{P})}$ index refers to a partial u0025 reduction of OC.

An oxidation step is needed to restore the oxy- p0205 gen carrier material to its original oxidation state $\left(\mathrm{Me}_{x} \mathrm{O}_{y}\right)$ and to produce $\mathrm{H}_{2}$ (when the oxidation step is carried out with steam). A difference is made whenever steam from air or water is used to regenerate the oxygen carrier material. The oxidation step performed with air is varied between steam reforming coupled with the chemicallooping combustion process (SR-CLC), where CLC is used to supply energy, which is needed for the conventional catalytic steam reforming, and the chemical-looping reforming process (CLR), where main products from the chemicallooping system are an $\mathrm{H}_{2}$ and $\mathrm{CO}$ mixture. Other processes use some oxygen-depleted materials to react with water steam to generate pure $\mathrm{H}_{2}$, also known as "water splitting." In this category, it can be found in chemical-looping hydrogen (CLH), or one step decarbonization (OSD) processes, and the so-called chemical-looping gasification

\section{ADVANCED SUSTAINABLE CHEMICAL PROCESSES AND CATALYSTS FOR ENVIRONMENT PROTECTION}


12

14. SPINEL MIXED OXIDES FOR CHEMICAL-LOOP REFORMING technologies: syngas chemical-looping process (SCL) and coal direct chemical-looping process (CDCL), etc. Usually the later processes need several oxidation steps, like an air treatment, which sometimes is required for the final regeneration of the oxygen carrier material [44]. Several indepth reviews [45-47] summarize information on the existing chemical-looping processes aligned to produce high purity hydrogen, and offer both the use of renewable and $\mathrm{CO}_{2}$-neutral feedstocks, as well as efficient $\mathrm{CO}_{2}$ sequestration capabilities [46].

\section{CHEMICAL-LOOP REFORMING (CLR) FOR HYDROGEN GENERATION}

p0210 CLR for hydrogen generation is developed as an alternative way to produce $\mathrm{H}_{2}$ starting from either conventional or renewable sources. The chemical-looping process can be performed using a number of different reductants, such as gas resulting from coal [13] or biomass [14-16] gasification, light hydrocarbons reforming [17], methane [18-20], $\mathrm{CH}_{4} / \mathrm{CO}_{2}$ and $\mathrm{CH}_{4} / \mathrm{H}_{2}$ mixture [20,21], pyrolysis oil [22,23], light alcohols [48-56], and pure $\mathrm{H}_{2}$ (as a method for $\mathrm{H}_{2}$ storage) $[25,26]$. Different from a classical reforming, separation costs can be avoided by splitting the process into two/three alternated steps in order to separate $\mathrm{H}_{2} / \mathrm{CO}_{x}$ streams and fully re-oxidize the oxygen carrier materials (Fig. 14.6). Generally, the reducing fuel $\left(\mathrm{C}_{n} \mathrm{H}_{2 m}\right)$ is fed to the feed reactor (FR), where it reacts with the oxygen carrier material $\left(\mathrm{M}_{x} \mathrm{O}_{y}\right)$ according to the following equation:

$$
\begin{aligned}
& (\text { FR })(n+m / 2) \mathrm{M}_{x} \mathrm{O}_{y}+\mathrm{C}_{n} \mathrm{H}_{2 m} \\
& \stackrel{\rightarrow}{\rightarrow}(n+m / 2) \mathrm{M}_{x} \mathrm{O}_{y-2}+m \mathrm{H}_{2} \mathrm{O}+n \mathrm{CO}_{2}
\end{aligned}
$$

After the first step, previously reduced oxygen p0215 carrier material is transferred to the steam reactor (SR), where it is oxidized by a water steam to restore its original oxidation state:

$$
\begin{aligned}
& (\text { SR }) \\
& \rightarrow(n+m / 2) \mathrm{M}_{x} \mathrm{O}_{y-2}+m \mathrm{H}_{2} \mathrm{O} \\
& \rightarrow(n+m / 2) \mathrm{M}_{x} \mathrm{O}_{y-1}+m \mathrm{H}_{2}
\end{aligned}
$$

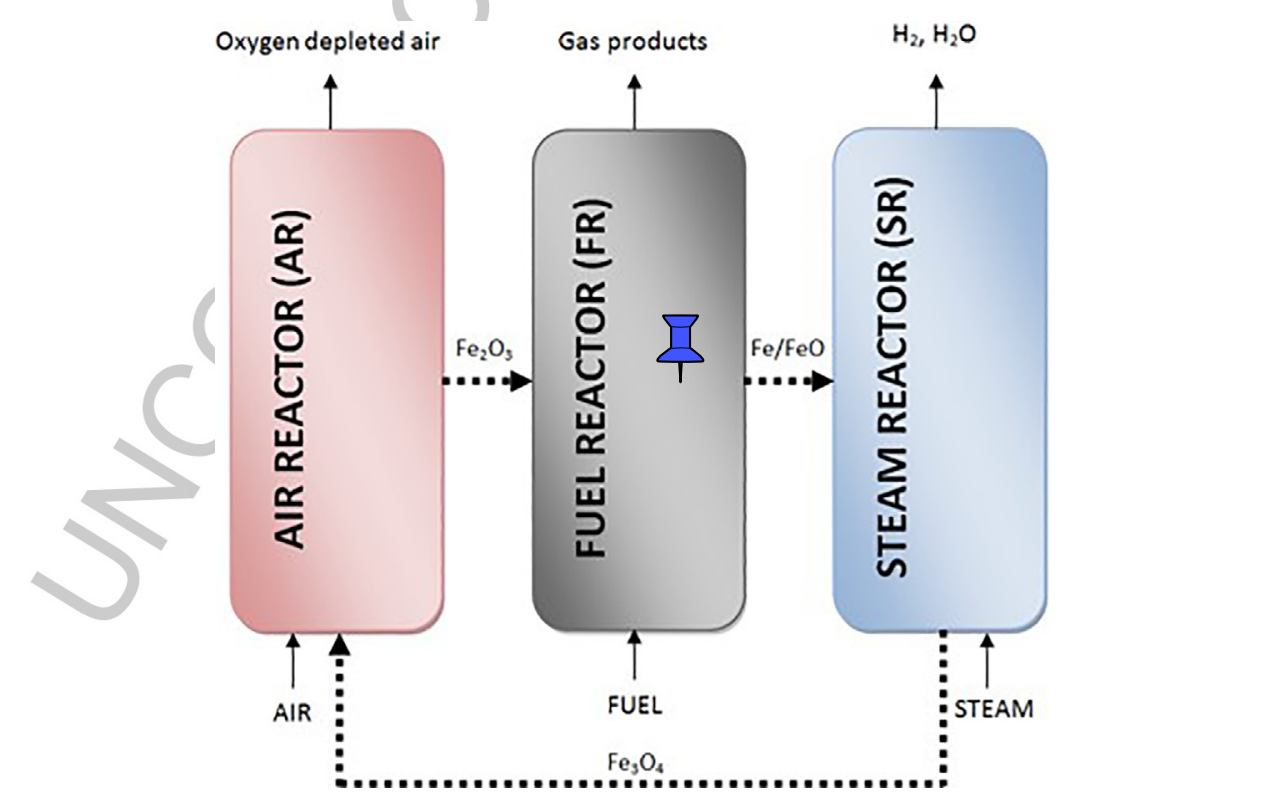

Q18 f0035 FIG. 14.6 Schematic representation of CLR for hydrogen generation over Fe-based oxygen carrier material. 
p0220 A general statement can be made on the basis of the results obtained independently by several research groups: as the oxygen ratio in the system decreases, there is a higher tendency toward carbon formation, which in its turn leads to the lowering of the purity of the produced hydrogen. According to Cho et al. [57], the rate of carbon formation increased rapidly when more than $80 \%$ of the available oxygen in the Ni-based oxygen carrier was consumed. Galvita and Sundmacher reported that a maximum $\mathrm{Fe}$ reduction of $60 \%$ largely minimized carbon formation and a high purity hydrogen stream $(<20$ ppm CO) could be obtained [58].

p0225 Usually, the difficulty to restore the original oxidation state of the oxygen carrier material by means of only water steam can lead to the necessity of an additional oxidation step, like an air treatment:

$$
\begin{aligned}
& (\mathbf{A R})(n+m / 2) \mathrm{M}_{x} \mathrm{O}_{y-1}+1 / 2 \mathrm{O}_{2} \\
& \rightarrow(n+m / 2) \mathrm{M}_{x} \mathrm{O}_{y}
\end{aligned}
$$

p0230 Oxygen carrier material $\left(\mathrm{M}_{x} \mathrm{O}_{y}\right)$, in its fully oxidized form, is further re-circulated to the fuel reactor (FR) for subsequent cycles.

p0235 Important aspects for the overall effectiveness of the process lie in the choice of operation conditions, appropriate reactor designs (fluidized bed [59-61]/moving bed [62]/fixed bed [63-66] reactors), and identification of suitable candidates to be used as corresponding oxygen carrier materials.

\section{s0100 5.1 Oxygen Carrier Materials}

p0240 One of the key parameters that determines the overall efficiency of many chemical-looping processes for hydrogen production, lies in the selection of a suitable oxygen carrier material, taking into account several properties: reaction kinetics, thermodynamic feasibility of oxygen transfer, redox properties, oxygen content, stability and recyclability, high resistance to attrition, heat capacity, melting points, tendency to form coke, resistance to coke formation and accumulation, low cost, toxicity, etc. [44]. Thus, many research groups focus their attention on the improvements of the activity and stability of the oxygen carrier material through optimization of its composition, screening of the supports along with the particle structure optimization. Ideally, appropriate oxygen carriers should have fairly high conversion rates in both reduction and re-oxidation reactions, high agglomeration/sintering resistance, maximum fuel conversion with minor carbon deposition, and be economically and environmentally friendly [67].

Reduction and oxidation reactions, which are p0245 the main prerequisite to any chemical-looping process, require additional information on the thermodynamic aspect of a suitable redox couple $-\mathrm{M}_{x} \mathrm{O}_{y} / \mathrm{M}_{x}$, which determines the final effectiveness of the process with a choice of operating conditions. In the review, published by Fan et al. [11], a comparative thermodynamic assessment of different oxygen carrier materials was made based on modified Ellingham diagram, where metal oxide materials can be grouped into several zones, depending on their applications. For example, materials like $\mathrm{V}_{2} \mathrm{O}_{5} / \mathrm{V}, \mathrm{CeO}_{2} / \mathrm{Ce}_{2} \mathrm{O}_{3}, \mathrm{WO}_{3} / \mathrm{W}$, or $\mathrm{ZnO} / \mathrm{Zn}$ are capable to only partially oxidize the fuel, whereas $\mathrm{NiO} / \mathrm{Ni}, \mathrm{Fe}_{2} \mathrm{O}_{3} / \mathrm{FeO}, \mathrm{CuO} / \mathrm{Cu}$, or $\mathrm{Co}_{3} \mathrm{O}_{4} / \mathrm{Co}$ have strong oxidizing properties and foster total oxidation reactions. Thus, $\mathrm{Ni}$, $\mathrm{Fe}, \mathrm{Co}$, and $\mathrm{Cu}$ metal oxides are often used as the main constituents of oxygen carrier materials for chemical-looping applications. A review published by Voitic et al. [46] covers data on the development of different oxygen carrier materials, and comprises studies on the naturally occurring and synthetically derived bulky or supported materials. In addition, a summary on the different oxygen carrier materials for the hydrogen production via chemical-looping processes was published by 
Protasova et al. [67]. The review encompasses information on the different perovskites and $\mathrm{Ni} / \mathrm{Fe} / \mathrm{Cu} / \mathrm{Ce}$-based oxygen carrier materials. Perovskites showed good results for the partial oxidation of methane. With Fe-based materials, promising results have also been obtained (they are considered replacements for Ni-based oxygen carriers because of their lower price and toxicity). Many studies were performed by testing different active metal component, namely, Fe, $\mathrm{W}, \mathrm{Sn}, \mathrm{Ni}, \mathrm{Cu}, \mathrm{Mn}$, and $\mathrm{Ce}$. However, more recent works were almost exceptionally focused on iron-based oxygen carriers combined with several inert components aimed to improve their mechanical and chemical properties. Several research groups have been exploring modifications of simple iron oxide $\left(\mathrm{Fe}_{3} \mathrm{O}_{4}\right.$ and $\mathrm{Fe}_{2} \mathrm{O}_{3}$ ) in order to prevent deactivation [68], lowering of the operating temperature [69] and increase of the structural stability and reducibility $[70,71]$, the reaction rate for oxidation, and the total efficiency of the process $[72,73]$. Several studies were dedicated to different metal additives to iron oxide $[74,75]$. In addition, ternary metal systems have also been considered in the search for a better synergetic effect $[76,77]$. Several research groups have investigated the effect of various M-additives on the stability and redox behavior of iron oxide for chemical hydrogen storage using $\mathrm{Pd}, \mathrm{Pt}, \mathrm{Rh}, \mathrm{Ru}, \mathrm{Al}, \mathrm{Ce}$, $\mathrm{Ti}, \mathrm{Zr}$ [78] and $\mathrm{Al}, \mathrm{Cr}, \mathrm{Zr}, \mathrm{Ga}, \mathrm{V}, \mathrm{Mo}$ [79]. And it was found out that $\mathrm{Pd}, \mathrm{Pt}, \mathrm{Rh}$, and $\mathrm{Ru}$ additives have an effect on promoting the reduction and lowering the re-oxidation temperature of iron oxide. At the same time, $\mathrm{Al}, \mathrm{Ce}, \mathrm{Ti}, \mathrm{Zr}, \mathrm{Cr}$, $\mathrm{Ga}$, and $\mathrm{V}$ additives prevent deactivation and sintering of iron oxide during repeated redox cycles. Some recent studies on developing novel and efficient oxygen carrier materials for chemicalloop applications highlight the special interest of spinel oxides $[18,26,68,69,72,73,80-90]$, which can be explained by their thermodynamic stability, which allows them to re-obtain the initial oxidized spinel phase upon redox cycling and increase the stability of the looping material.

\subsection{Spinel Oxides as Oxygen Carrier Materials}

Spinel oxides with a generic formula of $\mathrm{AB}_{2} \mathrm{O}_{4}$ are chemically and thermally stable materials suitable for various applications including catalysis. From a chemical aspect, spinels exhibit acidbase and redox properties, which play a key role in several catalytic reactions involving oxygen species [49]. Moreover, according to the nature of incorporated cations, they can host a variety of redox couples (e.g., $\mathrm{Fe}(\mathrm{II}) / \mathrm{Fe}(\mathrm{III}), \mathrm{Mn}$ (II)/ $\mathrm{Mn}(\mathrm{III})$, or $\mathrm{Co}(\mathrm{II}) / \mathrm{Co}(\mathrm{III}))$, which make them suitable materials for Chemical-Looping applications [91]. As a confirmation, several studies of different $\mathrm{M}$-modified $(\mathrm{M}=\mathrm{Ni}, \mathrm{Co}, \mathrm{Cu}, \mathrm{Mn})$ iron oxides of the spinel family have shown that the redox properties of these materials render them effective electrons and $\mathrm{O}^{2-}$ vectors for the production of hydrogen via chemical-loop reforming (CLR) of alcohols (mainly $\mathrm{C}_{1}-\mathrm{C}_{2}$ light alcohols) [48-56] (see Table 14.1, Scheme 14.1).

\subsection{Spinel Oxides for Methanol Chemical-Loop Reforming}

$\mathrm{CoFe}_{2} \mathrm{O}_{4}$ spinel oxide was applied as an oxy- p0255 gen carrier material in a two-step chemical-loop reforming process using methanol as a reductant $[48,50]$. The study performed by Crocellà et al. [48] revealed an evident correlation between physicochemical and catalytic properties of the looping material. Particularly, $\mathrm{CoFe}_{2} \mathrm{O}_{4}$ spinel was calcined at $450^{\circ} \mathrm{C}$ and $750^{\circ} \mathrm{C}(\mathrm{CF} 450$ and CF750, respectively) in order to evaluate an effect of different morphological features as crystallite-particle sizes on the methanol decomposition and a stepwise reduction of the solid. It was shown that surface octahedral sites $\left(\mathrm{Co}^{2+} / \mathrm{Fe}^{3+}\right)$ are the most reactive species, and are present in a higher amount on the $\mathrm{CoFe}_{2} \mathrm{O}_{4}$ sample calcined at a lower temperature (namely, $450^{\circ} \mathrm{C}$ ). However, it was demonstrated that two spinel oxides, initially rather different from one another, exhibited similar features after just

\section{ADVANCED SUSTAINABLE CHEMICAL PROCESSES AND CATALYSTS FOR ENVIRONMENT PROTECTION}


TABLE 14.1 Summarized Data on Spinel Oxides as Oxygen Carriers for Chemical-Looping Applications

\begin{tabular}{|c|c|c|c|c|c|c|}
\hline Reductant & Oxidant & $T_{\text {red }}\left({ }^{\circ} \mathrm{C}\right)$ & $T_{\mathrm{ox}}\left({ }^{\circ} \mathrm{C}\right)$ & Oxygen Carrier & Reduction Degree (\%) & Ref. \\
\hline $\mathrm{CH}_{3} \mathrm{OH}$ & $\mathrm{H}_{2} \mathrm{O}$ & $\begin{array}{l}300 \\
420\end{array}$ & 420 & $\begin{array}{l}\text { (a) } \mathrm{CoFe}_{2} \mathrm{O}_{4}(\mathrm{CF} 450) \\
\text { (b) } \mathrm{CoFe}_{2} \mathrm{O}_{4}(\mathrm{CF} 750)\end{array}$ & $\begin{array}{l}\text { (a) } 100^{\mathrm{T}(300)} \\
\text { (b) } 82^{\mathrm{T}(300)}\end{array}$ & Crocella [48] \\
\hline $\mathrm{CH}_{3} \mathrm{OH}$ & $\begin{array}{l}\mathrm{H}_{2} \mathrm{O} \\
\text { Air }\end{array}$ & $\begin{array}{l}\text { (a,b) } 300 \\
\text { (a) } 420\end{array}$ & $\begin{array}{l}420^{\mathrm{H}_{2} \mathrm{O}} \\
450^{\mathrm{AIR}}\end{array}$ & $\begin{array}{l}\text { (a) } \mathrm{CoFe}_{2} \mathrm{O}_{4}(\mathrm{CF} 450) \\
\text { (b) } \mathrm{CoFe}_{2} \mathrm{O}_{4}(\mathrm{CF} 750)\end{array}$ & $\begin{array}{l}\text { (a) } 100^{\mathrm{T}(300)} \\
\text { (a) } 100^{\mathrm{T}(420)} \\
\text { (b) } 82^{\mathrm{T}(300)}\end{array}$ & Cocchi [50] \\
\hline $\mathrm{C}_{2} \mathrm{H}_{5} \mathrm{OH}$ & $\mathrm{H}_{2} \mathrm{O}$ & - & - & $\begin{array}{l}\text { (a) } \mathrm{CoFe}_{2} \mathrm{O}_{4}(\mathrm{CF} 450) \\
\text { (b) } \mathrm{Fe}_{3} \mathrm{O}_{4}(\mathrm{FF} 450) \\
\text { (c) } \mathrm{NiFe}_{2} \mathrm{O}_{4}(\mathrm{NF} 450)\end{array}$ & & Velasquez Ochoa [56] \\
\hline $\mathrm{C}_{2} \mathrm{H}_{5} \mathrm{OH}$ & $\mathrm{H}_{2} \mathrm{O}$ & 450 & 450 & $\begin{array}{l}\text { (a) } \mathrm{Fe}_{3} \mathrm{O}_{4} \text { (FF450) } \\
\text { (b) } \mathrm{NiFe}_{2} \mathrm{O}_{4} \text { (NF450) }\end{array}$ & $\begin{array}{l}\text { (a) } 57 \\
\text { (b) } 69\end{array}$ & Trevisanut [53] \\
\hline $\mathrm{C}_{2} \mathrm{H}_{5} \mathrm{OH}$ & $\mathrm{H}_{2} \mathrm{O}$ & 450 & 450 & $\mathrm{Fe}_{3} \mathrm{O}_{4}$ & - & Trevisanut [55] \\
\hline $\mathrm{C}_{2} \mathrm{H}_{5} \mathrm{OH}$ & $\mathrm{H}_{2} \mathrm{O}$ & 450 & 450 & $\begin{array}{l}\text { (a) } \mathrm{CoFe}_{2} \mathrm{O}_{4} \\
\text { (b) } \mathrm{Fe}_{3} \mathrm{O}_{4} \\
\text { (c) } \mathrm{NiFe}_{2} \mathrm{O}_{4} \\
\text { (d) } \mathrm{CuFe}_{2} \mathrm{O}_{4}\end{array}$ & $\begin{array}{l}\text { (a) } 78 \\
\text { (b) } 29 \\
\text { (c) } 52 \\
\text { (d) } 53\end{array}$ & Trevisanut [52] \\
\hline $\mathrm{C}_{2} \mathrm{H}_{5} \mathrm{OH}$ & $\mathrm{H}_{2} \mathrm{O}$ & 450 & & $\begin{array}{l}\text { (a) } \mathrm{Co}_{0.6} \mathrm{Fe}_{2.4} \mathrm{O}_{y} \\
\text { (b) } \mathrm{Co}_{0.54} \mathrm{Mn}_{0.06} \mathrm{Fe}_{2.4} \mathrm{O} \\
\text { (c) } \mathrm{Co}_{0.3} \mathrm{Mn}_{0.3} \mathrm{Fe}_{2.4} \mathrm{O}_{y} \\
\text { (d) } \mathrm{Mn}_{0.6} \mathrm{Fe}_{2.4} \mathrm{O}_{y}\end{array}$ & $\begin{array}{l}\text { (a) } 98 \\
\text { (b) } 100 \\
\text { (c) } 32 \\
\text { (d) } 19\end{array}$ & Vozniuk [54] \\
\hline $\mathrm{C}_{2} \mathrm{H}_{5} \mathrm{OH}$ & $\mathrm{H}_{2} \mathrm{O}$ & & 450 & $\begin{array}{l}\text { (a) } \mathrm{CoFe}_{2} \mathrm{O}_{4} \\
\text { (b) } \mathrm{Cu}_{0.5} \mathrm{Co}_{0.5} \mathrm{Fe}_{2} \mathrm{O}_{4} \\
\text { (c) } \mathrm{CuFe}_{2} \mathrm{O}_{4} \\
\text { (d) } \mathrm{Cu}_{0.5} \mathrm{Mn}_{0.5} \mathrm{Fe}_{2} \mathrm{O}_{4} \\
\text { (e) } \mathrm{Co}_{0.5} \mathrm{Mn}_{0.5} \mathrm{Fe}_{2} \mathrm{O}_{4} \\
\text { (f) } \mathrm{MnFe}_{2} \mathrm{O}_{4}\end{array}$ & $\begin{array}{l}\text { (a) } 82 \\
\text { (b) } 100 \\
\text { (c) } 82 \\
\text { (d) } 73 \\
\text { (e) } 10 \\
\text { (f) } 8\end{array}$ & Vozniuk [51] \\
\hline $\mathrm{C}_{2} \mathrm{H}_{5} \mathrm{OH}$ & & $\begin{array}{l}450 \\
350\end{array}$ & 450 & $\begin{array}{l}\text { (a) } \mathrm{CoFe}_{2} \mathrm{O}_{4} \\
\text { (b) } \mathrm{FeCo}_{2} \mathrm{O}_{4}\end{array}$ & - & $\begin{array}{l}\text { Carraro and Vozniuk } \\
\text { [49] }\end{array}$ \\
\hline
\end{tabular}

one reduction/re-oxidation cycle, where the surface properties of CF450 and CF750 were irreversibly modified. Reduction of the solids was performed at $300^{\circ} \mathrm{C}$ and $420^{\circ} \mathrm{C}$ and, based on the product's distribution, different reaction zones (I-IV) were distinguished. Thus, during the early stage of the reduction, methanol conversion reached $19 \%$ and $\mathrm{CO}, \mathrm{CO}_{2}$, and $\mathrm{H}_{2}$

\section{ADVANCED SUSTAINABLE CHEMICAL PROCESSES AND CATALYSTS FOR ENVIRONMENT PROTECTION}


16 14. SPINEL MIXED OXIDES FOR CHEMICAL-LOOP REFORMING

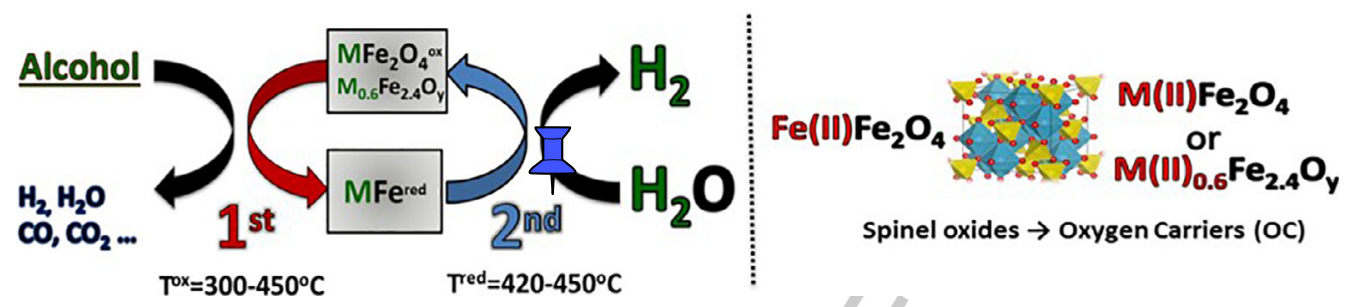

Q19 sch0010 SCHEME 14.1 Chemical-loop reforming of alcohols with spinel oxides as oxygen carriers.

(with small amount of $\mathrm{CH}_{4}, \mathrm{H}_{2} \mathrm{O}$ and other oxygenates) were detected as initially formed products. With increasing the reduction time (specifically, solid exposure to the reactants stream), coke and $\mathrm{CO}_{2}$ were produced in a higher amount, whereas methanol conversion and the solid reduction reached their maximum $(X=88 \%$ and $\alpha=100^{\mathrm{CF} 450} / 82^{\mathrm{CF} 750 \%} \%$, where $X=$ conversion and $\alpha=$ degree of reduction). Further research on the $\mathrm{CoFe}_{2} \mathrm{O}_{4}$ as a looping material was performed by Cocchi et al. [50]. It was confirmed that the reduction degree of the solid, together with the temperature at which reduction was carried out, significantly affected the methanol conversion and product's distribution. A higher reduction temperature $\left(420^{\circ} \mathrm{C}\right)$ led to an increase of the solid reduction rate, despite all occurred phenomena were similar to those observed at $300^{\circ} \mathrm{C}$. Moreover, it was found that a complete recovery of the initial oxidation state of Co-ferrites was not possible using only $\mathrm{H}_{2} \mathrm{O}$ as an oxidant and a third step with air was added. The material obtained after the three-step CLR process showed quite similar reactivity results to that of the freshly calcined $\mathrm{CoFe}_{2} \mathrm{O}_{4}$ samples. This indicates that a complete restoration of the spinel phase was possible even after the formation of both metallic species and Fe carbide compounds during the first reduction step.

\section{s0115 5.4 Spinel Oxides for Ethanol Chemical-Loop Reforming}

p0260 Based on the two steps discussed, the chemical-looping reforming process, in which different M-modified spinel oxides were used as oxygen carrier materials, Trevisanut et al. $[52,53,55]$ investigated ethanol as a reducing agent. The choice of ethanol as a reducing agent has several advantages, including its renewable origin, and the possibility to decompose at a relatively lower temperature with the formation of a hydrogen-rich mixture [54]. A study performed on a bare $\mathrm{Fe}_{3} \mathrm{O}_{4}$ sample [55] showed that magnetite during the reduction step tends to form $\mathrm{Fe}^{0}$ which is then converted to $\mathrm{Fe}_{3} \mathrm{C}$ (cementite). However, the formed carbide can decompose to metallic iron and carbon $\left(\mathrm{Fe}_{3} \mathrm{C} \rightarrow 3 \mathrm{Fe}^{0}+\mathrm{C}\right)$ and, similarly, catalyze growth of graphitic filaments and increase the rate of coke deposition. In order to reduce formation and accumulation of coke during several consecutive redox cycles, it was proposed to apply a short time on-stream approach (with reduction time of $5 \mathrm{~min}$ ), because the formation of cementite was slightly delayed at the beginning of the reduction step. Reducibility of magnetite was improved by incorporation of several transition metals like $\mathrm{Co}, \mathrm{Cu}$, and $\mathrm{Ni}$ into the spinel structure [52,53]. Eventually, coke formation remained an issue for M-modified ferrospinels, which means that to avoid a completely carbon deposition and its further accumulation is not possible. Nevertheless, the best-performing material amongst tested oxygen carriers was $\mathrm{CoFe}_{2} \mathrm{O}_{4}$, which underwent the greatest extent of reduction and was able to maintain it throughout several repeated cycles [52].

Velasquez Ochoa et al. [56] studied the reduc- p0265 tion mechanism of M-modified ( $\mathrm{Ni}, \mathrm{Co}$, and $\mathrm{Fe}$ ) spinel oxides, where ethanol was the reductant.

\section{ADVANCED SUSTAINABLE CHEMICAL PROCESSES AND CATALYSTS FOR ENVIRONMENT PROTECTION}


It was concluded that the first step in ethanol anaerobic decomposition appears to be the same for all samples and corresponds to acetaldehyde formation via dehydrogenation of ethanol. Further reduction of the solid was strongly dependent on the nature of incorporated $\mathrm{M}(\mathrm{Ni}, \mathrm{Co}$, or $\mathrm{Fe}$ ), specifically, acetaldehyde can be either oxidized to acetates $\left(\mathrm{NiFe}_{2} \mathrm{O}_{4}\right)$, decomposed to $\mathrm{CO}$ and $\mathrm{CH}_{4}\left(\mathrm{CoFe}_{2} \mathrm{O}_{4}\right)$, or completely oxidized $\left(\mathrm{Fe}_{3} \mathrm{O}_{4}\right)$. Vozniuk et al. investigated binary and ternary mixed-spinel oxides $\left(\mathrm{M}_{x}^{1} \mathrm{M}_{0.6-x}^{2} \mathrm{Fe}_{2.4} \mathrm{O}_{y}\right.$ and $\mathrm{M}_{x}^{1} \mathrm{M}_{1-x}^{2} \mathrm{Fe}_{2} \mathrm{O}_{4}$, where $\mathrm{M}=\mathrm{Co}, \mathrm{Mn}, \mathrm{Cu}$ ) as oxygen carrier materials in two-step CLR of ethanol. It was observed that the incorporation of $\mathrm{Mn} / \mathrm{Co}$ metal cations into $\mathrm{Fe}_{3} \mathrm{O}_{4}$ crystal structure affects the reducibility of the resulting spinels (Fe-rich ferrospinel: $\mathrm{M}_{x}^{1} \mathrm{M}_{0.6-x}^{2} \mathrm{Fe}_{2.4} \mathrm{O}_{y}$ ). Co incorporation was found to enhance reactivity in the anaerobic decomposition/oxidation of ethanol, whereas Mn incorporation significantly reduced the coke formation during the first reduction step [54]. Consecutive studies on the $\mathrm{M}_{x}^{1} \mathrm{M}_{1-x}^{2} \mathrm{Fe}_{2} \mathrm{O}_{4}$ as oxygen carriers revealed that $\mathrm{Co} / \mathrm{Cu}$-incorporation facilitates total/partial oxidation of ethanol giving rise to high yields of $\mathrm{H}_{2}, \mathrm{CO}_{x}$, and $\mathrm{H}_{2} \mathrm{O}$, whereas Mn-incorporation predominantly favored dehydrogenation and condensation reactions leading to the formation of acetaldehyde and acetone. Besides, the incorporation of $\mathrm{Mn}$ contributed to significantly reduce the amount of coke that was attributed to the formation of a thermodynamically stable and hardly reducible layer of $\mathrm{Mn}_{x} \mathrm{Fe}_{y} \mathrm{O}$ solid solution [51]. A study on $\mathrm{CoFe}_{2} \mathrm{O}_{4}$ and $\mathrm{FeCO}_{2} \mathrm{O}_{4}$ as oxygen carrier materials was performed by Carraro et al. [49]. During the reduction step with ethanol, $\mathrm{FeCO}_{2} \mathrm{O}_{4}$ was reduced faster compared with $\mathrm{CoFe}_{2} \mathrm{O}_{4}$. However, its performance during the re-oxidation step is quite poor due to an inefficient oxidation by water steam, which is able to oxidize only the outer shell of the nanoparticles, resulting in small $\mathrm{H}_{2}$ yield [49]. On the other hand, the $\mathrm{CoFe}_{2} \mathrm{O}_{4}$ sample was a more efficient oxygen carrier, which enables it to produce larger amounts of $\mathrm{H}_{2}$ due to the residual presence of a reducible wüstite, which can be consecutively re-oxidized/reduced in further looping cycles.

\subsection{Summary on Spinel Oxides as Oxygen s0120 Carrier Materials}

A variety of studies have been performed on p0270 ferrospinels of different compositions $\left(\mathrm{MFe}_{2} \mathrm{O}_{4}\right.$ and $\mathrm{M}_{0.6} \mathrm{Fe}_{2.4} \mathrm{O}_{y}$, where $\mathrm{M}=\mathrm{Fe}, \mathrm{Ni}, \mathrm{Cu}, \mathrm{Co}$, and $\mathrm{Mn}$ ), whereby the following general statements can be made:

1. The incorporation of transition metals, such as $\mathrm{Ni}, \mathrm{Cu}, \mathrm{Co}$, and $\mathrm{Mn}$ (or their combinations $\mathrm{Cu} / \mathrm{Co}, \mathrm{Co} / \mathrm{Mn}, \mathrm{Cu} / \mathrm{Mn}$ ), strongly affects final redox properties of the resulting materials. Overall, the reducibility of magnetite $\left(\mathrm{Fe}_{3} \mathrm{O}_{4}\right)$ is enhanced with the introduction of secondary metals $(\mathrm{Co}, \mathrm{Ni}$, and $\mathrm{Cu}$ ) into the spinel structure. Besides, its presence in a smaller amount (as in $\mathrm{M}_{0.6} \mathrm{Fe}_{2.4} \mathrm{O}_{y}$ type materials, with Fe:M ratio of 4:1) is already sufficient to observe positive results on the production of $\mathrm{H}_{2}$ via a two-step chemical-looping reforming process compared with nonmodified $\mathrm{Fe}_{3} \mathrm{O}_{4}$.

2. The incorporation of Mn contributed to significantly reducing the amount of coke formed, however, it caused a lower intrinsic reducibility which was explained by the formation of a thermodynamically stable and hardly reducible layer of $\mathrm{Mn}_{x} \mathrm{Fe}_{y} \mathrm{O}$ solid solution. It is important to note that the final purity of hydrogen is limited by the coke which is formed during the reduction step. As mentioned earlier, this problem can be partially overcome by changing the spinel composition, or shortening the overall time of the redox cycles to 5 or $20 \mathrm{~min}$ (time accounts to the total time of reduction/re-oxidation step) (note: the problem of an impure stream 07 can also be overcome by the utilization of a three-step CLR process with the third step being carried out with air [92].

\section{ADVANCED SUSTAINABLE CHEMICAL PROCESSES AND CATALYSTS FOR ENVIRONMENT PROTECTION}


p0285 Nonetheless, another challenge needs to be tackled in the future; with each performed cycle the material tends to deactivate as the result of:

00055 1. Deep modification of the starting material via sintering and segregation phenomena,

00060 2. Continuous or sequential "coking" of the material with each performed cycle due to the impossibility to achieve a total removal in the conventional CLR process,

o0065 3. Incomplete re-oxidation of the metallic component $\left(\mathrm{M}^{0}\right)$ using just $\mathrm{H}_{2} \mathrm{O}$ as an oxidant.

p0305 On the other hand, modifying the conventional two-step process by adding the third step with air helped to overcome these problems, and is a first approach to overcome the above-described limitations [92]. As a general conclusion, it needs to be underlined that the chemical-looping reforming (CLR) process remains a very attractive target for researchers and industry in particular, and the future global energy economy in general. Many efforts to reach this goal have been undertaken and are reviewed herein. From the discovery the CLR process went to pilot plant stage but never managed to truly become economically viable. The future focus of researchers needs to be steered toward the current shortcomings of the process. Despite that several improved looping materials have been proposed, nonsintering and noncoking catalysts need to be conceived. Moreover, complete appraisals of their performance and further optimization studies are required in order to give information on the overall conversion efficiencies, process design, and economics.

\section{CONCLUSIONS}

p0310 Interest in hydrogen, as an energy carrier, has been extensively growing in recent decades, which is powered by its environmental advantages over classical energy sources such as natural gas and coal. At this point, the future perspective of a hydrogen economy has triggered many researchers to develop and optimize a series of new technologies which differ from conventional industrial processes (like SMR, ATR, $\mathrm{POX}$, and $\mathrm{H}_{2} \mathrm{O}$-electrolysis) in their orientation toward minimization of emission of greenhouse gases (on-site $\mathrm{CO}_{2}$ capture), utilization of renewable feedstock (bio-alcohols, bio-gases, wood, and algae), or renewable energy sources (wind, sunlight, or tides).

One of the new technologies, which is aimed p0315 to produce hydrogen in a more sustainable manner, is chemical-looping hydrogen or chemicallooping water splitting process. Initially, the chemical-looping concept was oriented on the combustion of different fuel feedstocks to generate heat and power, called the chemical-loop combustion process; only later it was applied to the generation of hydrogen. Over the last decades, this approach has been extensively investigated by many research groups, and more than 100 chemical-looping cycles with different operating parameters, engineering challenges, and hydrogen production opportunities are described in the literature. Ideally, the chemicallooping process is aimed to produce high purity hydrogen without any additional separation steps that are the issues of today's industrial processes. Eventually, this technology may offer several other opportunities for process intensification through selection of the oxygen carrier materials and design of the reaction paths which can be either partial or total oxidation of the fuel, generating a variety of products ranging from syngas and hydrogen to olefins and liquid fuels (Schemes 14.2-14.4). Summary schemes indicates that hydrogen remains to be a target product, however, overall efficiency of the chemical-loop processes can be maximized by converting reducing fuels into valuable products (Schemes 14.3 and 14.4).

Several chemical-looping pilot and sub-pilot p0320 plants [93-95] went on stream but have not been successfully demonstrated commercially to the date. The main reason deals with oxygen carrier materials, namely, their insufficiency in

\section{ADVANCED SUSTAINABLE CHEMICAL PROCESSES AND CATALYSTS FOR ENVIRONMENT PROTECTION}




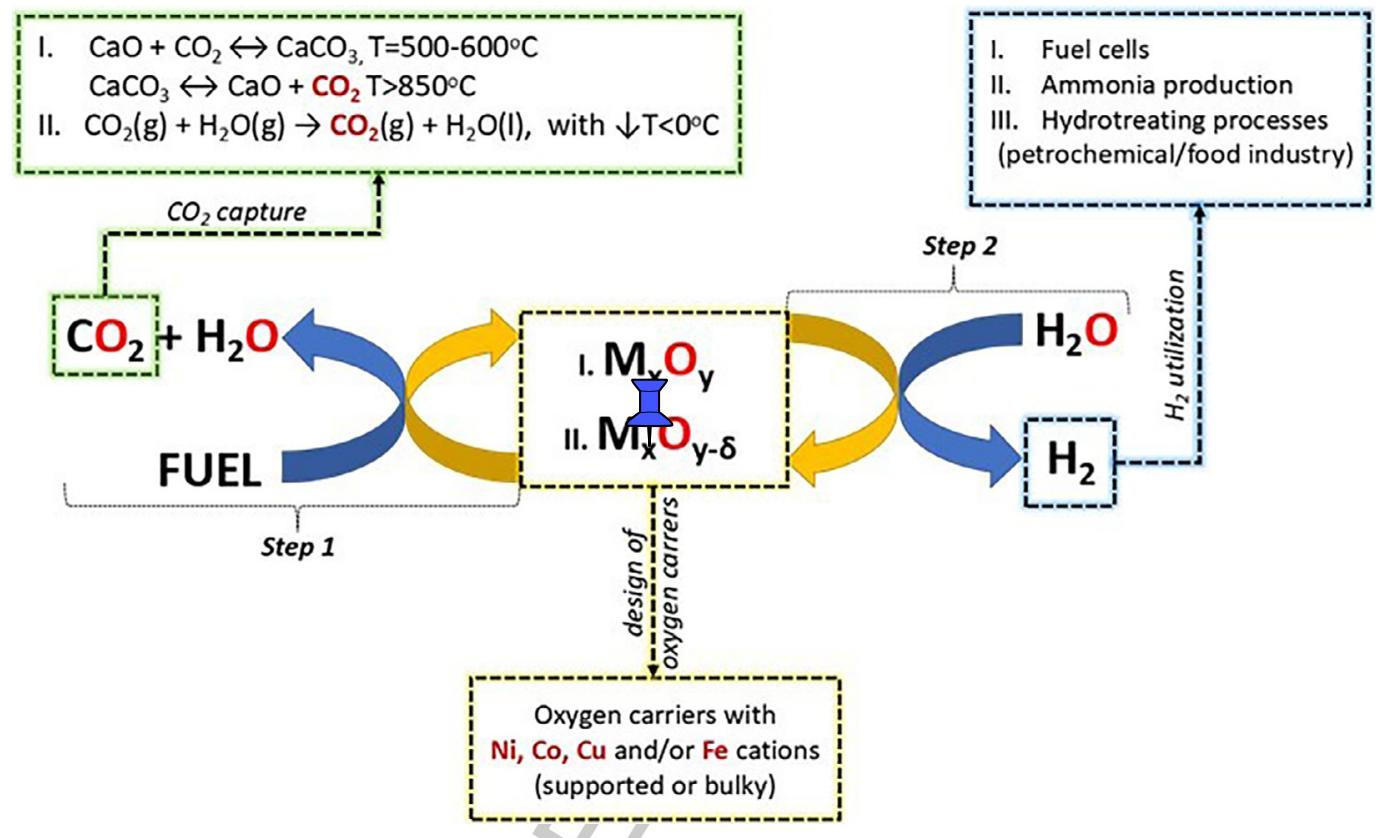

Q20 sch0015 SCHEME 14.2 Hydrogen production with inherent on-site $\mathrm{CO}_{2}$ capture and separation.

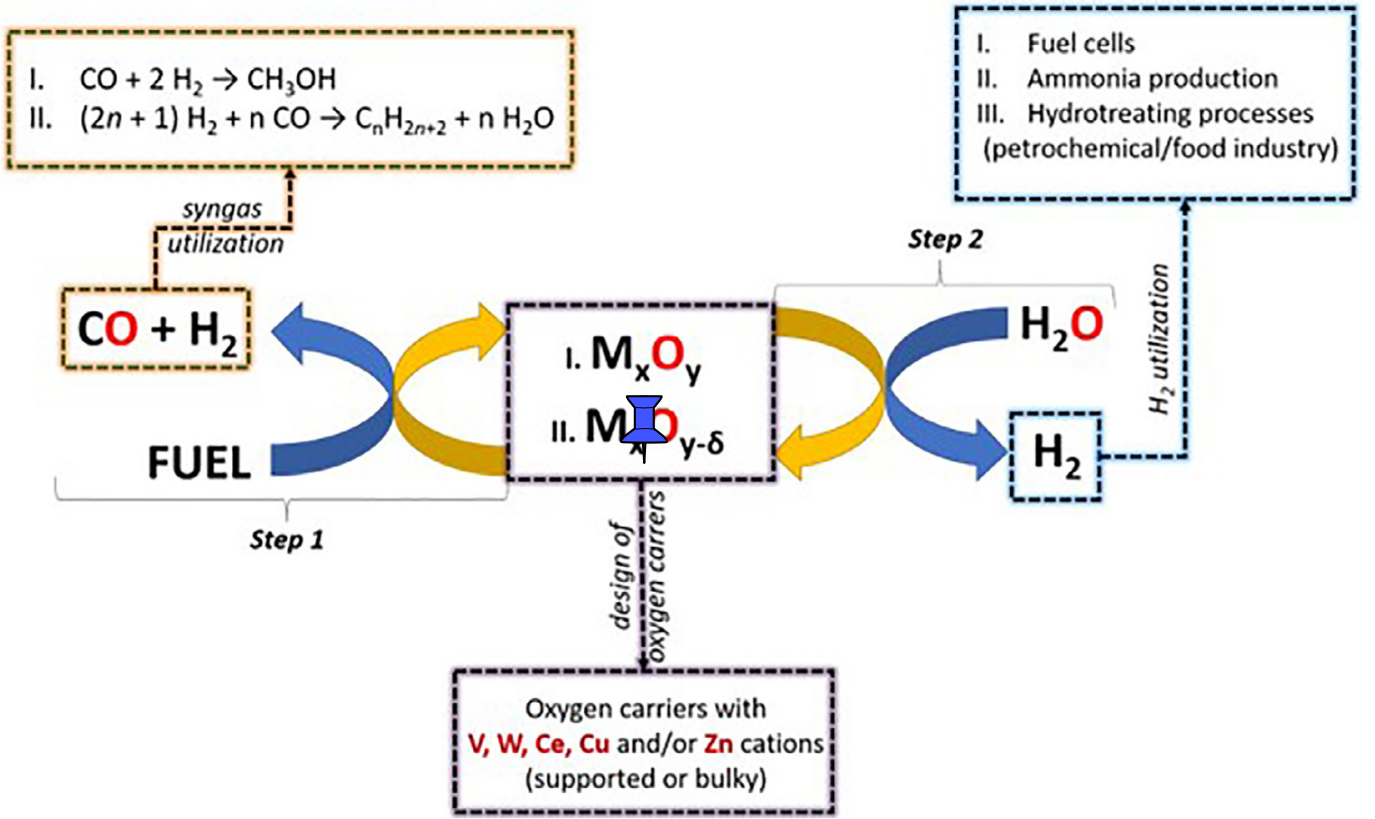

Q21 sch0020 SCHEME 14.3 Hydrogen production with on-site simultaneous syngas generation. 


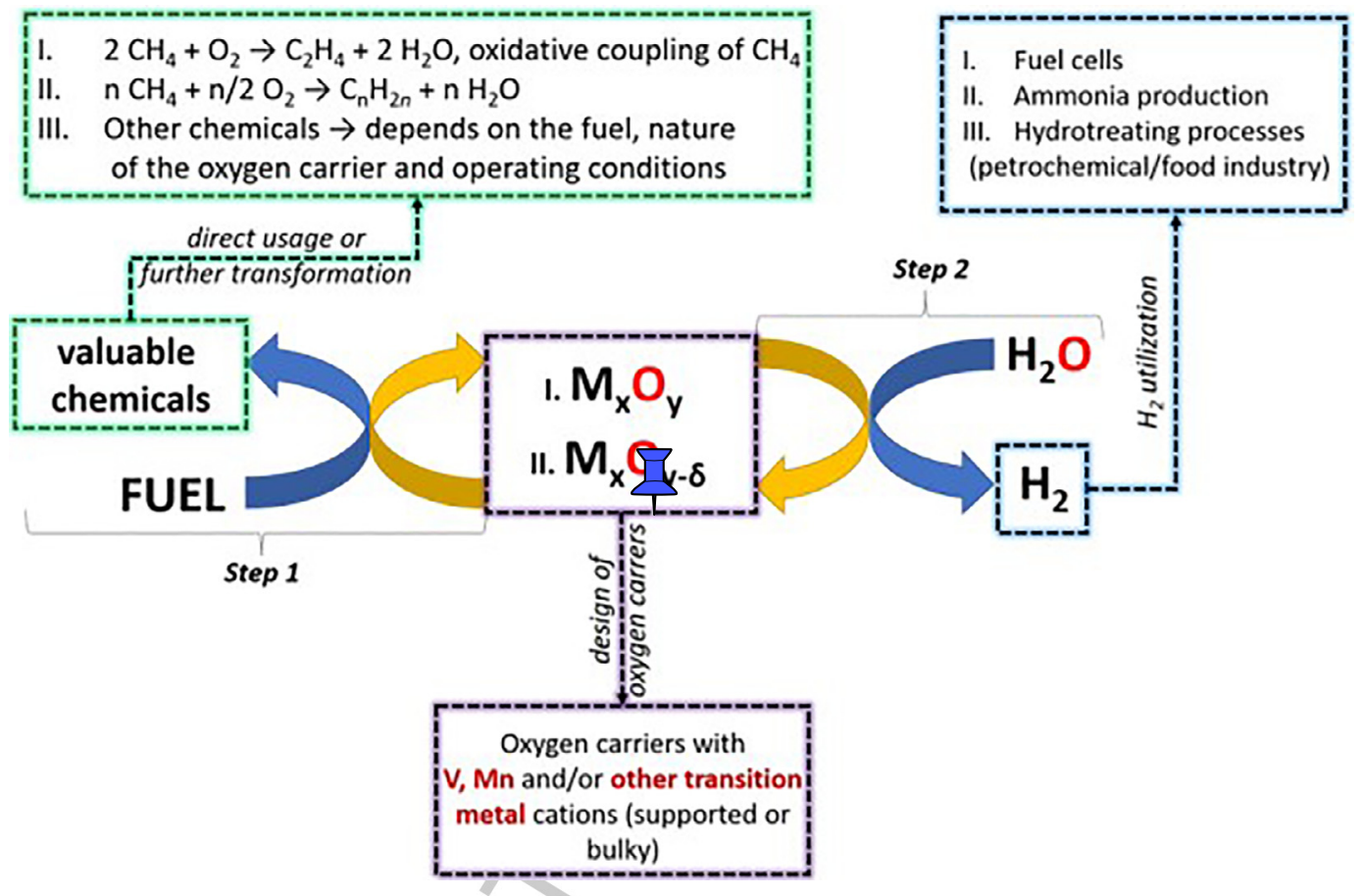

Q22 sch0025 SCHEME 14.4 Hydrogen production with on-site simultaneous co-production of other chemicals.

reactivity, stability and recyclability, physical strength and attrition resistance, tendency to form and accumulate coke, and oxygen-carrying capacity. Another reason is linked to the reactors design and solid circulatory systems, specifically the lack of design know-how on high-solid loading flows, nonmechanical devices, and gassolid reactors for achieving high oxygen-carrier conversions [11]. Despite the remaining challenges, ongoing research in this field brings new solutions to the existing limitations, which gives a potential to the chemical-looping technology.

\section{References}

[1] R.M. Navarro, M.C. Sánchez-Sánchez, M.C. AlvarezGalvan, F. Del Valle, J.L.G. Fierro, Hydrogen production from renewable sources: biomass and photocatalytic opportunities, Energy Environ. Sci. 2 (2009) 35-54.

[2] G. Tsekouras, D. Neagu, J.T.S. Irvine, Step-change in high temperature steam electrolysis performance of perovskite oxide cathodes with exsolution of B-site dopants, Energy Environ. Sci. 6 (2013) 256-266.

[3] B.K. Boggs, R.L. King, G.G. Botte, Urea electrolysis: direct hydrogen production from urine, Chem. Commun. (2009) 4859-4861.

[4] T. Lazarides, M. Delor, I.V. Sazanovich, T. M. McCormick, I. Georgakaki, G. Charalambidis, J. A. Weinstein, A.G. Coutsolelos, Photocatalytic hydrogen production from a noble metal free system based on a water soluble porphyrin derivative and a cobaloxime catalyst, Chem. Commun. 50 (2014) 521-523.

[5] J.W. Jurss, R.S. Khnayzer, J.A. Panetier, K.A. El Roz, E. M. Nichols, M. Head-Gordon, J.R. Long, F. N. Castellano, C.J. Chang, Bioinspired design of redox-active ligands for multielectron catalysis: effects of positioning pyrazine reservoirs on cobalt for electro- and photocatalytic generation of hydrogen from water, Chem. Sci. 6 (2015) 4954-4972.

[6] M. Ni, D.Y.C. Leung, M.K.H. Leung, A review on reforming bio-ethanol for hydrogen production, Int. J. Hydrogen Energy 32 (2007) 3238-3247.

[7] L. Chen, C.K.S. Choong, Z. Zhong, L. Huang, T.P. Ang, L. Hong, J. Lin, Carbon monoxide-free hydrogen production via low-temperature steam reforming of ethanol over iron-promoted Rh catalyst, J. Catal. 276 (2010) 197-200.

\section{ADVANCED SUSTAINABLE CHEMICAL PROCESSES AND CATALYSTS FOR ENVIRONMENT PROTECTION}


[8] F. Fresno, T. Yoshida, N. Gokon, R. FernándezSaavedra, T. Kodama, Comparative study of the activity of nickel ferrites for solar hydrogen production by two-step thermochemical cycles, Int. J. Hydrogen Energy 35 (2010) 8503-8510.

[9] P. Charvin, S. Abanades, G. Flamant, F. Lemort, Twostep water splitting thermochemical cycle based on iron oxide redox pair for solar hydrogen production, Energy 32 (2007) 1124-1133.

[10] N. Hanada, S. Hino, T. Ichikawa, H. Suzuki, K. Takai, Y. Kojima, Hydrogen generation by electrolysis of liquid ammonia, Chem. Commun. 46 (2010) 7775-7777.

[11] L.-S. Fan, L. Zeng, S. Luo, Chemical-looping technology platform, AICHE J. 61 (2015) 2-22.

[12] H. Lane, Process for the production of hydrogen, US 1078686, 1913.

[13] P. Gupta, L.G. Velazquez-Vargas, L.-S. Fan, Syngas redox (SGR) process to produce hydrogen from coal derived syngas, Energy Fuel 21 (2007) 2900-2908.

[14] V. Hacker, R. Fankhauser, G. Faleschini, H. Fuchs, K. Friedrich, M. Muhr, K. Kordesch, Hydrogen production by steam-iron process, J. Power Sources 86 (2000) 531-535.

[15] V. Hacker, G. Faleschini, H. Fuchs, R. Fankhauser, G. Simader, M. Ghaemi, B. Spreitz, K. Friedrich, Usage of biomass gas for fuel cells by the SIR process, J. Power Sources 71 (1998) 226-230.

[16] R. Sime, J. Kuehni, L. D'Souza, E. Elizondo, S. Biollaz, The redox process for producing hydrogen from woody biomass, Int. J. Hydrogen Energy 28 (2003) 491-498.

[17] V. Hacker, A novel process for stationary hydrogen production: the reformer sponge iron cycle (RESC), J. Power Sources 118 (2003) 311-314.

[18] K. Go, S. Son, S. Kim, K. Kang, C. Park, Hydrogen production from two-step steam methane reforming in a fluidized bed reactor, Int. J. Hydrogen Energy 34 (2009) 1301-1309.

[19] K. Go, S. Son, S. Kim, Reaction kinetics of reduction and oxidation of metal oxides for hydrogen production, Int. J. Hydrogen Energy 33 (2008) 5986-5995.

[20] K. Otsuka, A. Mito, S. Takenaka, I. Yamanaka, Production of hydrogen from methane without $\mathrm{CO}_{2}$-emission mediated by indium oxide and iron oxide, Int. J. Hydrogen Energy 26 (2001) 191-194.

[21] V.V. Galvita, H. Poelman, G.B. Marin, Hydrogen production from methane and carbon dioxide by catalyst-assisted chemical looping, Top. Catal. 54 (2011) 907-913.

[22] M. Bleeker, S. Gorter, S. Kersten, L. van der Ham, H. van den Berg, H. Veringa, Hydrogen production from pyrolysis oil using the steam-iron process: a process design study, Clean Technol. Environ. Policy 12 (2009) 125-135.
[23] M.F. Bleeker, S.R.A. Kersten, H.J. Veringa, Pure hydrogen from pyrolysis oil using the steam-iron process, Catal. Today 127 (2007) 278-290.

[24] R. Campo, P. Durán, J. Plou, J. Herguido, J.A. Peña, Combined production and purification of hydrogen from methanol using steam iron process in fixed bed reactor, J. Power Sources 242 (2013) 520-526.

[25] J.A. Peña, E. Lorente, E. Romero, J. Herguido, Kinetic study of the redox process for storing hydrogen: reduction stage, Catal. Today 116 (2006) 439-444.

[26] E. Lorente, J.A. Peña, J. Herguido, Separation and storage of hydrogen by steam-iron process: effect of added metals upon hydrogen release and solid stability, J. Power Sources 192 (2009) 224-229.

[27] S. Walspurger, W.G. Haije, B. Louis, $\mathrm{CO}_{2}$ reduction to substitute natural gas: toward a global low carbon energy system, Isr. J. Chem. 54 (2014) 1432-1442.

[28] K. Aasberg-Petersen, C. Stub Nielsen, I. Dybkjær, J. Perregaard, Large Scale Methanol Production From Natural Gas, Haldor Topsøe, Lyngby, 2014.

[29] M. Götz, J. Lefebvre, M. Friedemann, G. Manuel, A. McDaniel Koch, F. Graf, S. Bajohr, R. Reimert, T. Kolb, Renew. Energy 85 (2016) 1371-1390.

[30] P. Losch,(Ph.D. thesis), Université de Strasbourg, 2016.

[31] S.A. Ghoneim, R.A. El-Salamony, S.A. El-Temtamy, Review on innovative catalytic reforming of natural gas to syngas, World J. Eng. Technol. 4 (2016) 116-139.

[32] M. Garcia-Dieguez, I.S. Pieta, M.C. Herrera, M. A. Larrubia, I. Malpartida, Transient study of the dry reforming of methane over $\mathrm{Pt}$ supported on different $\gamma-\mathrm{Al}_{2} \mathrm{O}_{3}$, Catal. Today 149 (2010) 380-387.

[33] M.A. Peña, J.P. Gomez, J.L.G. Fierro, New catalytic routes for syngas and hydrogen production, Appl. Catal. A Gen. 144 (1996) 7-57.

[34] S.R. Craig, A. Grimes, O.K. Varghese, Light, Water, Hydrogen: The Solar Generation of Hydrogen by Water Photoelectrolysis, Springer, Boston, MA, 2008.

[35] P. Varadhan, H. Fu, D. Priante, J. Ramon, D. Retamal, C. Zhao, M. Ebaid, T.K. Ng, I. Ajia, S. Mitra, I. S. Roqan, B.S. Ooi, J.-H. He, Surface passivation of $\mathrm{GaN}$ nanowires for enhanced photoelectrochemical water-splitting, Nano Lett. 17 (2017) 1520-1528.

[36] K.J. Kadassery, S.K. Dey, A.F. Cannella, R. Surendhran, D.C. Lacy, Photochemical water-splitting with organomanganese complexes, Inorg. Chem. 56 (2017) 9954-9965.

[37] S.T. Kochuveedu, Photocatalytic and photoelectrochemical water splitting on $\mathrm{TiO}_{2}$ via photosensitization, J. Nanomater. (2016) 4073142.

[38] R. Dholam, N. Patel, M. Adami, A. Miotello, Hydrogen production by photocatalytic water-splitting using $\mathrm{Cr}$ or Fe-doped $\mathrm{TiO}_{2}$ composite thin films photocatalyst, Int. J. Hydrogen Energy 34 (2009) 5337-5346.

\section{ADVANCED SUSTAINABLE CHEMICAL PROCESSES AND CATALYSTS FOR ENVIRONMENT PROTECTION}


[39] I. Roger, M.A. Shipman, M.D. Symes, Earth-abundant catalysts for electrochemical and photoelectrochemical water splitting, Nat. Rev. Chem 1 (2017) 0003.

[40] S.Y. Tee, K.Y. Win, W.S. Teo, L. Koh, S. Liu, C.P. Teng, M.Y. Han, Recent progress in energy-driven water splitting, Adv. Sci. 4 (2017).

[41] R.D. Tentu, S. Basu, Photocatalytic water splitting for hydrogen production, Curr. Opin. Electrochem. 5 (2017) 56-62.

[42] C.L. Muhich, B.D. Ehrhart, I. Al-shankiti, B.J. Ward, C. B. Musgrave, A.W. Weimer, A review and perspective of efficient hydrogen generation via solar thermal water splitting, WIREs Energy Environ. 5 (2016) 261-287.

[43] J. Orfila, M. Linares, M. Molina, R. Botas, J.A. Sanz, R. Marugan, Perovskite materials for hydrogen production by thermochemical water splitting, Int. J. Hydrogen Energy 41 (2016) 19329-19338.

[44] J. Adanez, A. Abad, F. Garcia-Labiano, P. Gayan, L.F. de Diego, Progress in chemical-looping combustion and reforming technologies, Prog. Energy Combust. Sci. 38 (2012) 215-282.

[45] B. Moghtaderi, Review of the recent chemical looping process developments for novel energy, fuel applications, Energy Fuel 26 (2012) 15-40.

[46] G. Voitic, V. Hacker, Recent advancements in chemical looping water splitting for the production of hydrogen, RSC Adv. 6 (2016) 98267-98296.

[47] M. Luo, Y. Yi, S. Wang, Z. Wang, M. Du, J. Pan, Q. Wang, Review of hydrogen production using chemicallooping technology, Renew. Sustain. Energy Rev. 81 (2018) 3186-3214.

[48] V. Crocellà, F. Cavani, G. Cerrato, S. Cocchi, G. Magnacca, C. Morterra, On the role of morphology of $\mathrm{CoFeO}_{4}$ spinel in methanol anaerobic oxidation, J. Phys. Chem. C 116 (2012) 14998-15009.

[49] F. Carraro, O. Vozniuk, L. Calvillo, L. Nodari, C. La Fontaine, F. Cavani, S. Agnoli, In operando XAS investigation of reduction and oxidation processes in cobalt and iron mixed spinels during the chemical loop reforming of ethanol, J. Mater. Chem. A 5 (2017) 20808-20817.

[50] S. Cocchi, M. Mari, F. Cavani, J.-M.M. Millet, Chemical and physical behavior of $\mathrm{CoFe}_{2} \mathrm{O}_{4}$ in steam-iron process with methanol, Appl. Catal. B Environ. 152-153 (2014) 250-261.

[51] O. Vozniuk, C. Bazzo, S. Albonetti, N. Tanchoux, F. Bosselet, J.-M.M. Millet, F. Di Renzo, F. Cavani, Structural changes of binary/ternary spinel oxides during ethanol anaerobic decomposition, ChemCatChem 9 (2017) 2219-2230.

[52] C. Trevisanut, O. Vozniuk, M. Mari, S.Y.A. Urrea, C. Lorentz, J.M.M. Millet, F. Cavani, The chemical-loop reforming of alcohols on spinel-type mixed oxides: comparing $\mathrm{Ni}, \mathrm{Co}$, and Fe ferrite vs magnetite performances, Top. Catal. 59 (2016) 1600-1613.

[53] C. Trevisanut, M. Mari, J.M.M. Millet, F. Cavani, Chemical-loop reforming of ethanol over metal ferrites: an analysis of structural features affecting reactivity, Int. J. Hydrogen Energy 40 (2014) 5264-5271.

[54] O. Vozniuk, S. Agnoli, L. Artiglia, A. Vassoi, N. Tanchoux, F. Di Renzo, G. Granozzi, F. Cavani, Towards an improved process for hydrogen production: the chemical-loop reforming of ethanol, Green Chem. 18 (2016) 1038-1050.

[55] C. Trevisanut, F. Bosselet, F. Cavani, J.M.M. Millet, A study of surface and structural changes of magnetite cycling material during chemical looping for hydrogen production from bio-ethanol, Catal. Sci. Technol. 5 (2015) 1280-1289.

[56] J.V. Ochoa, C. Trevisanut, J.-M.M. Millet, G. Busca, F. Cavani, In situ DRIFTS-MS study of the anaerobic oxidation of ethanol over spinel mixed oxides, J. Phys. Chem. C 117 (2013) 23908-23918.

[57] P. Cho, T. Mattisson, A. Lyngfelt, Carbon formation on nickel and iron oxide-containing oxygen carriers for chemical-looping combustion, Ind. Eng. Chem. Res. 44 (2005) 668-676.

[58] V. Galvita, K. Sundmacher, Hydrogen production from methane by steam reforming in a periodically operated two-layer catalytic reactor, Appl. Catal. A Gen. 289 (2005) 121-127.

[59] G.T. Jin, H.J. Ryu, S.H. Jo, S.Y. Lee, S.R. Son, S.D. Kim, Hydrogen production in fluidized bed by chemicallooping cycle, Korean J. Chem. Eng. 24 (2007) 542-546.

[60] L.F. de Diego, M. Ortiz, F. García-Labiano, J. Adánez, A. Abad, P. Gayán, Hydrogen production by chemical-looping reforming in a circulating fluidized bed reactor using Ni-based oxygen carriers, J. Power Sources 192 (2009) 27-34.

[61] M. Rydén, M. Arjmand, Continuous hydrogen production via the steam-iron reaction by chemical looping in a circulating fluidized-bed reactor, Int. J. Hydrogen Energy 37 (2012) 4843-4854.

[62] A. Tong, L. Zeng, M.V. Kathe, D. Sridhar, L. Fan, Application of the moving-bed chemical looping process for high methane conversion, Energy Fuel 27 (2013) 4119-4128.

[63] R.D. Solunke, G. Veser, Hydrogen production via chemical looping steam reforming in a periodically operated fixed-bed reactor, Ind. Eng. Chem. Res. 49 (2010) 11037-11044.

[64] B. Jiang, B. Dou, Y. Song, C. Zhang, B. Du, H. Chen, C. Wang, Y. Xu, Hydrogen production from chemical looping steam reforming of glycerol by Ni-based oxygen carrier in a fixed-bed reactor, Chem. Eng. J. 280 (2015) 459-467.

\section{ADVANCED SUSTAINABLE CHEMICAL PROCESSES AND CATALYSTS FOR ENVIRONMENT PROTECTION}


[65] K. Wang, B. Dou, B. Jiang, Y. Song, C. Zhang, Q. Zhang, H. Chen, Y. Xu, Renewable hydrogen production from chemical looping steam reforming of ethanol using $\mathrm{xCeNi} / \mathrm{SBA}-15$ oxygen carriers in a fixed-bed reactor, Int. J. Hydrogen Energy 41 (2016) 12899-12909.

[66] B. Dou, B. Jiang, Y. Song, C. Zhang, C. Wang, H. Chen, B. Du, Y. Xu, Enhanced hydrogen production by sorption-enhanced steam reforming from glycerol with in-situ $\mathrm{CO}_{2}$ removal in a fixed-bed reactor, Fuel 166 (2016) 340-346.

[67] L. Protasova, F. Snijkers, Recent developments in oxygen carrier materials for hydrogen production via chemical looping processes, Fuel 181 (2016) 75-93.

[68] K.-S. Cha, H.-S. Kim, B.-K. Yoo, Y.-S. Lee, K.-S. Kang, C.S. Park, Y.-H. Kim, Reaction characteristics of two-step methane reforming over a $\mathrm{Cu}$-ferrite $/ \mathrm{Ce}-\mathrm{ZrO}_{2}$ medium, Int. J. Hydrogen Energy 34 (2009) 1801-1808.

[69] K.-S. Kang, C.-H. Kim, W.-C. Cho, K.-K. Bae, S.-W. Woo, C.-S. Park, Reduction characteristics of $\mathrm{CuFe}_{2} \mathrm{O}_{4}$ and $\mathrm{Fe}_{3} \mathrm{O}_{4}$ by methane; $\mathrm{CuFe}_{2} \mathrm{O}_{4}$ as an oxidant for two-step thermochemical methane reforming, Int. J. Hydrogen Energy 33 (2008) 4560-4568.

[70] D. Yamaguchi, L. Tang, L. Wong, N. Burke, D. Trimm, K. Nguyen, K. Chiang, Hydrogen production through methane-steam cyclic redox processes with iron-based metal oxides, Int. J. Hydrogen Energy 36 (2011) 6646-6656.

[71] S. Takenaka, N. Hanaizumi, V. Son, K. Otsuka, Production of pure hydrogen from methane mediated by the redox of $\mathrm{Ni}^{-}$and $\mathrm{Cr}$-added iron oxides, J. Catal. 228 (2004) 405-416.

[72] K.-S. Kang, C.-H. Kim, K.-K. Bae, W.-C. Cho, W.-J. Kim, Y.-H. Kim, S.-H. Kim, C.-S. Park, Redox cycling of $\mathrm{CuFe}_{2} \mathrm{O}_{4}$ supported on $\mathrm{ZrO}_{2}$ and $\mathrm{CeO}_{2}$ for two-step methane reforming/water splitting, Int. J. Hydrogen Energy 35 (2010) 568-576.

[73] T. Kodama, T. Shimizu, T. Satoh, M. Nakata, Stepwise production of CO-rich syngas and hydrogen via solar methane reforming by using a $\mathrm{Ni}(\mathrm{II})$-ferrite redox system, Sol. Energy 73 (2002) 363-374.

[74] K. Otsuka, T. Kaburagi, C. Yamada, S. Takenaka, Chemical storage of hydrogen by modified iron oxides, J. Power Sources 122 (2003) 111-121.

[75] E. Lorente, J.A. Peña, J. Herguido, Cycle behaviour of iron ores in the steam-iron process, Int. J. Hydrogen Energy 36 (2011) 7043-7050.

[76] S. Takenaka, T. Kaburagi, C. Yamada, K. Nomura, K. Otsuka, Storage and supply of hydrogen by means of the redox of the iron oxides modified with Mo and Rh species, J. Catal. 228 (2004) 66-74.

[77] S. Takenaka, K. Nomura, N. Hanaizumi, K. Otsuka, Storage and formation of pure hydrogen mediated by the redox of modified iron oxides, Appl. Catal. A Gen. 282 (2005) 333-341.
[78] J.C. Ryu, D.H. Lee, K.S. Kang, C.S. Park, J.W. Kim, Y. H. Kim, Effect of additives on redox behavior of iron oxide for chemical hydrogen storage, J. Ind. Eng. Chem. 14 (2008) 252-260.

[79] K. Otsuka, C. Yamada, T. Kaburagi, S. Takenaka, Hydrogen storage and production by redox of iron oxide for polymer electrolyte fuel cell vehicles, Int. J. Hydrogen Energy 28 (2003) 335-342.

[80] V.J. Aston, B.W. Evanko, A.W. Weimer, Investigation of novel mixed metal ferrites for pure $\mathrm{H}_{2}$ and $\mathrm{CO}_{2}$ production using chemical looping, Int. J. Hydrogen Energy 38 (2013) 9085-9096.

[81] S. Bhavsar, B. Tackett, G. Veser, Evaluation of iron- and manganese-based mono- and mixed-metallic oxygen carriers for chemical looping combustion, Fuel 136 (2014) 268-279.

[82] F.-X. Chiron, G.S. Patience, Kinetics of mixed copperiron based oxygen carriers for hydrogen production by chemical looping water splitting, Int. J. Hydrogen Energy 37 (2012) 10526-10538.

[83] F.-X. Chiron, G.S. Patience, S. Rifflart, Hydrogen production through chemical looping using $\mathrm{NiO} / \mathrm{NiAl}_{2} \mathrm{O}_{4}$ as oxygen carrier, Chem. Eng. Sci. 66 (2011) 6324-6330.

[84] C.-C. Cormos, Evaluation of iron based chemical looping for hydrogen and electricity co-production by gasification process with carbon capture and storage, Int. J. Hydrogen Energy 35 (2010) 2278-2289.

[85] M. Källén, P. Hallberg, M. Rydén, T. Mattisson, A. Lyngfelt, Combined oxides of iron, manganese and silica as oxygen carriers for chemical-looping combustion, Fuel Process. Technol. 124 (2014) 87-96.

[86] S. Lorentzou, A. Zygogianni, K. Tousimi, C. Agrafiotis, A.G. Konstandopoulos, Advanced synthesis of nanostructured materials for environmental applications, J. Alloys Compd. 483 (2009) 302-305.

[87] M. Luo, S. Wang, L. Wang, M. Lv, Reduction kinetics of iron-based oxygen carriers using methane for chemicallooping combustion, J. Power Sources 270 (2014) 434-440.

[88] M.G. Rosmaninho, F.C.C. Moura, L.R. Souza, R. K. Nogueira, G.M. Gomes, J.S. Nascimento, M. C. Pereira, J.D. Fabris, J.D. Ardisson, M.S. Nazzarro, K. Sapag, M.H. Araújo, R.M. Lago, Investigation of iron oxide reduction by ethanol as a potential route to produce hydrogen, Appl. Catal. B Environ. 115-116 (2012) 45-52.

[89] M. Rydén, M. Källén, D. Jing, A. Hedayati, T. Mattisson, A. Lyngfelt, $\left(\mathrm{Fe}_{1-\mathrm{x}} \mathrm{Mn}_{\mathrm{x}}\right) \mathrm{Ti}_{\mathrm{y}} \mathrm{O}_{3}$ based oxygen carriers for chemical-looping combustion and chemical-looping with oxygen uncoupling, Energy Procedia 51 (2014) 85-98.

[90] S. Yang, K. Kim, J. Baek, J. Kim, J.B. Lee, C.K. Ryu, G. Lee, Spinel $\mathrm{Ni}(\mathrm{Al}, \mathrm{Fe})_{2} \mathrm{O}_{4}$ solid solution as an oxygen carrier for chemical looping combustion, Energy Fuel 26 (2012) 4617-4622.

\section{ADVANCED SUSTAINABLE CHEMICAL PROCESSES AND CATALYSTS FOR ENVIRONMENT PROTECTION}


[91] K. Svoboda, A. Siewiorek, D. Baxter, J. Rogut, M. Pohořelý, Thermodynamic possibilities and constraints for pure hydrogen production by a nickel and cobalt-based chemical looping process at lower temperatures, Energy Convers. Manag. 49 (2008) 221-231.

[92] O. Vozniuk, (Ph.D. thesis), Universita di Bologna and Ecole Nationale Superieure de Chimie de Montpellier, 2017.

[93] A. Tong, D. Sridhar, Z. Sun, H.R. Kim, L. Zeng, F. Wang, D. Wang, M.V. Kathe, S. Luo, Y. Sun, L.-S. Fan, Continuous high purity hydrogen generation from a syngas chemical looping $25 \mathrm{~kW}$ th sub-pilot unit with $100 \%$ carbon capture, Fuel 103 (2013) 495-505.

[94] T. Pröll, J. Bolhar-Nordenkampf, P. Kolbitsch, H. Hofbauer, Syngas and a separate nitrogen/argon stream via chemical looping reforming-A $140 \mathrm{~kW}$ pilot plant study, Fuel 89 (2010) 1249-1256.

[95] D. Sridhar, A. Tong, H. Kim, L. Zeng, F. Li, L.-S. Fan, Syngas chemical looping process: design and construction of a $25 \mathrm{~kW}_{\text {th }}$ subpilot unit, Energy Fuel 26 (2012) 2292-2302.

\section{Further Reading}

[96] T. Riis, E.F. Hagen, J.S. Vie, P.J.S. Vie, Ø. Ulleberg, G. Sandrock, Hydrogen Production and Storage; R\&D Priorities and Gaps, OECD/IEA, 2006.

[97] D. Yamaguchi, L. Tang, N. Burke, K. Chiang, L. Rye, T. Hadley, S. Lim, Small Scale Hydrogen Production From Metal-Metal Oxide Redox Cycles, INTECH, 2012. 


\title{
Non-Print Items
}

\begin{abstract}
Interest in hydrogen as a possible energy vector is powered by the depletion of fossil fuel feedstocks as well as concerns over global warming, which brings new environmental legislations on the emission of greenhouse gases into the atmosphere. At this point, the future perspective of a hydrogen economy has triggered many researchers to develop and optimize a series of new technologies which differ from conventional industrial processes (like SMR, ATR, POX, and $\mathrm{H}_{2} \mathrm{O}$-electrolysis) in their orientation toward the minimization of emission of greenhouse gases (on-site $\mathrm{CO}_{2}$ capture), utilization of renewable feedstock (bio-alcohols, bio-gases, wood, and algae), or renewable energy sources (wind, sunlight, or tides). This chapter gathers information on the most relevant technologies for hydrogen production, including discussions on existing conventional reforming processes, as well as developments in advanced and more environmentally benign methods, like chemical-looping.
\end{abstract}

Keywords: Hydrogen, Water splitting, Chemical looping, Alcohol reforming, Oxygen carriers, Spinel oxides, Ferrites 